\title{
State of the art of biofuels from Pure Plant Oil
}

\author{
D. Russo ${ }^{\text {a, }}{ }^{b}$, M. Dassisti ${ }^{a}$, V. Lawlor ${ }^{b}$ and A. G. Olabi ${ }^{b}$ \\ a Department of Mechanical and Management Engineering, Politecnico di Bari, Bari, Italy. \\ ${ }^{b}$ Department of Mechanical and Manufacturing Engineering, School of Mechanical Eng., Dublin City University, \\ Dublin 9, Ireland.
}

danila.russo2@mail.dcu.ie; m.dassisti@poliba.it; abdul.olabi@dcu.ie

\begin{abstract}
The pollution caused by fuel combustion either for mechanical or electrical energy generation purposes is nowadays one of the most important environmental issues. It has been proven that combustion emissions, particularly those from cars and trucks, are linked with severe damages to the environment and human health. Along with the environmental problems, is necessary to consider that fossil resources are declining and their exploitation is getting more and more expensive. Bioenergy represent a sustainable solution for energy generation. Bioenergy is renewable energy made from plant-derived organic matter, collectively termed "biomass". Biomass-based energy sources are potentially carbon dioxide neutral and recycle the same carbon atoms. Life cycle assessments are reported to evaluate the net environmental impacts of biofuels. The term biofuel refers to liquid or gaseous fuels for the internal combustion engines that are predominantly produced from biomass. Biofuel policy might capitalize on the production of biofuels supporting rural economic development and sustainable agriculture. Amongst biofuels pure plant oil (PPO) has been investigated. This paper sets out to review the state of the art for PPO use as fuel in diesel engines, based on a wide literature review.
\end{abstract}

Keywords: Biofuels, Pure Plant Oil, Life Cycle Analysis, SWOT Analysis.

\section{INTRODUCTION}

Fuels from crude oil supply about $96 \%$ of the worldwide energy demand for transportation [1]. On the other hand, known petroleum reserves are limited and will eventually run out. Various studies put the date of the global peak in oil production between 1996 and 2035 ([29]). Declining supplies of fossil energy resources such as oil, coal, natural gas, as well as the high cost of dependency on their importation are core problems that European Union countries must face; this is the rationale of several strategies to promote the use of biofuels (see REFUEL project in [10]). Fossil fuels fatal flaw is that its reserves may be $80 \%$ depleted within 35-84 years, depending on how rapidly it is used. Based on current projections, with the actual rate of consumption, global oil reserves are expected to last at least 44 years[11], without considering possible undiscovered mineral deposits that might prolong fossil's supply for other 20-40 years[12], [13].

Renewable energy systems seem a promise to solve all these problems, granting many countries energy supply security and being environmentally friendly. There are many reasons for the interest in biofuels; amongst all we cite: 
- mitigate climate change and reduce dependency on energy imports,

- the production of renewable energy to substitute the conventional fossil fuels, even though effectiveness of this replacement is still questionable [14];

- the virtually global commitment to reduce greenhouse gas emissions (GGE),

- the development of local resources: support to companies and small-scale producers, well-being and added value

- significant cost savings in transportation [15].

The concept of renewability quantification is interesting to apply to better address these aspects, evaluating in particular the restoration work with respect to the produced work (see, e.g., renewability indicator in [16]).

Depletion of global fossil oil joint to climate change and global warming issue have driven European Union energy policy towards three main goals: (a) assure security energy supply reducing dependency on oil imports, which will lead to (b) strengthen the countries economy guaranteeing, at the same time, the environmental protection[1], [17], [18] .

Among all sectors, the one that more is dependent on fossil fuels is the transportation sector. Diesel engines are broadly used in the transport, electricity generation, construction equipment and stand-by power generators[19], [20]. These sectors are heavy consumers of petroleum oils that are susceptible to be partially or totally replaced by biomass fuels, and their derivatives, derivable from agriculture and thus of renewable origin [20-26]. One interesting note on this concern is from [27], who highlights the need to evaluate the thermodinamical efficiency of making a fuel transportable (in the liquid form), since this factor might help to understand the most promising feedstocks to endeavour for the transportation, with particular concern to the pure plants.

The use of pure plant oil or PPO is yet marginal, but it seems to be very interesting for its future potential [28].

\subsection{Biofuels and their use in diesel engines}

The term biofuel refers to those liquid or gaseous fuels, used for the transport sector, that are predominantly produced from biomass[29], [30]. Only biodiesel and bioethanol are presently produced as a fuel on an industrial scale: a short history in their use and production is provided in [31] or [32]. Biodiesel is one of the candidate alternative energy sources that fulfills sustainable criteria because it is renewable and produced from domestic resources with less environmental impact, but also because it is biodegradable and non-toxic [33]. Increased use of biofuels offers many benefits, as well as sustainability, reduction of greenhouse gas emissions, and decreased reliance on foreign oil [17], [34]. Besides being a renewable source, in fact, such oils are $\mathrm{CO} 2$ neutral and contain little, if any sulfur, nitrogen and metals, which are major pollutants in current fuel emissions [35].

A variety of fuels can be derived from biomass resources including liquid fuels ${ }^{1}$, such as hydrogen and methane [36]. The use of biofuels is wide since they are mainly used in vehicles but are suitable in engines or fuel cells for electricity generation. Several strategies has been

\footnotetext{
${ }^{1}$ For liquid fuels are meant all those combustible with similar chemical and physical properties to fossil fuels, that can be used in diesel engines.
} 
experimented for their application to the transportation sector since 80's (see for instance the results reported in [37].

Due to their low sulphur levels, biofuels have insignificant sulphur dioxide $\mathrm{SO}_{2}$ emissions compared to diesel oil. Furthermore many of them present also low nitrogen levels[17], [30], [38], [39]. Nevertheless the biggest difference between biofuels and fossil fuels is oxygen content: biofuels present oxygen levels of 10 up to $45 \%$ while petroleum has essentially none [23][40]. The high oxygen content, if on one hand causes poor thermal stability and lower volatility[40], on the other hand contributes to a complete fuel oxidation, thus to a complete evaporation of the liquid fuel[41].

Essentially, liquid biofuels may be made from a variety of biomass sources through a number of conversion routes. Feedstock for their production are mainly the so called "firstgeneration" and "second generation" conversion pathways depending on the scope of crops, namely food use or biofuel dedicated one, and then the third generation [18] crops which are designed exclusively for fuels production and are commonly referred to as "energy crops"(such as perennial grasses, fast growing trees, and algae): this matter is of extreme importance for biofuel policy deployment ([42],[43]) . The core of sustainability question is the balance between subtraction of direct or indirect human feeding resources (e.g. subtracting arable land [44], the biofuel controversy in [45]) versusCO2 emission reduction for transportation. Mainly, biofuels fall into the following categories:

(a) Vegetable oils and biodiesels,

(b) Alcohols,

(c) Bio crude and synthetic oils.

Production of biofuels corresponds only to $1 \%$ of fuel requirements at the present day; it is expected to reach $7 \%$ in 2030 passing from a first generation of today to the carbon negative biofuels of 2030 [46]. The question of sustainability of biofuels is of great interest indeed to the present reasoning too, thus stressing on the importance of LCA concern for comparing biofuels ([28], [33], [44], [47-50]). Also blending strategies of pure oils with liquid hydrocarbon fuels seems to be an effective strategy to pursue [51].

Figure 1 shows the sources of main liquid biofuels for diesel engines.

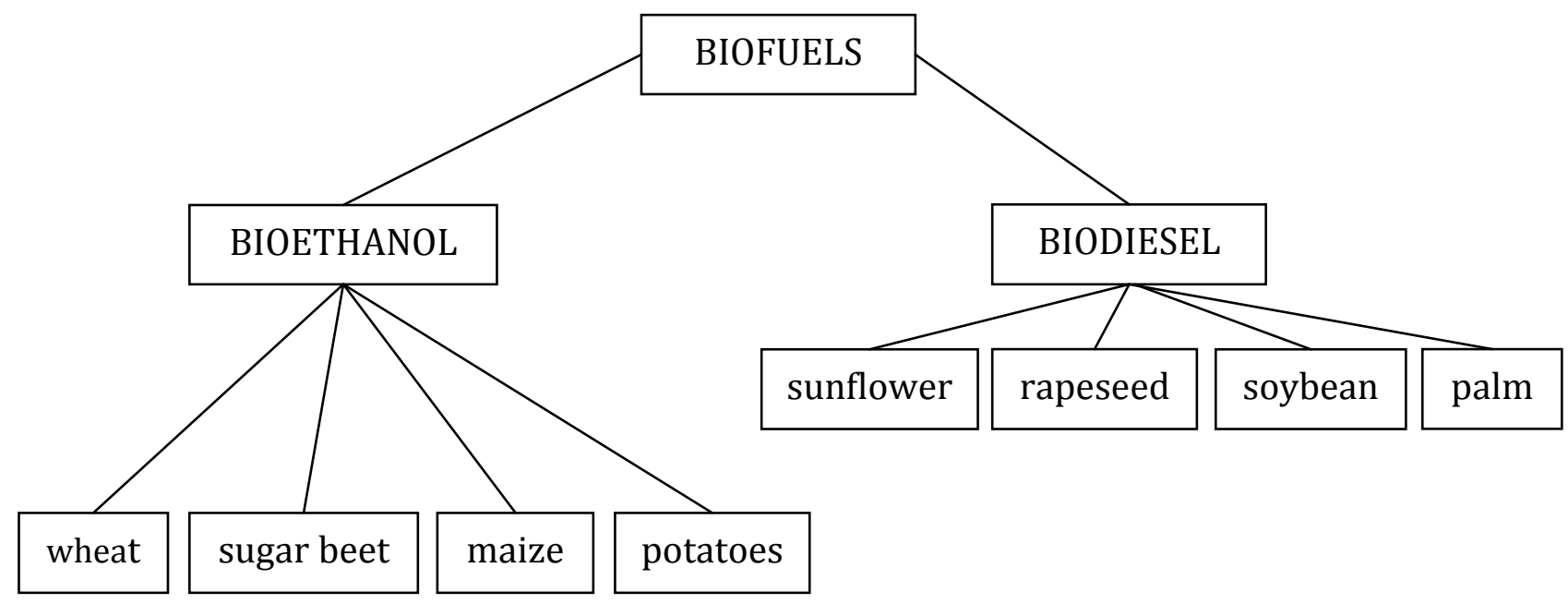


Fig. 1: sources of main liquid biofuels for automobiles. [30]

The use of plant oils in compression ignition (CI) engines is not new: Rudolf Diesel, the inventor of the engine that bears his name, during the Paris Exposition of 1900 exhibited his very first engines fuelled with peanut oil. These early uses were sporadic and petroleum derived fuels soon emerged as the dominant transportation fuel, although in the few decades, the increased costs of gasoline and the depletion of fossil feed stocks has led to a significant growing in the consumption of fuels derived from plant oil. Currently about $0.7 \%$ of worldwide diesel fuels derive from vegetable oil[52], [53], using several different processes for upgrading their properties for combustion purposes (pyrolisis [54], [55]; an overall review is provided in [35], cathalitic cracking [56], [57][58])

\subsection{Features of common vegetable oils}

Plant derived oils can be obtained from a wide variety of oilseed plants such as sunflower, rapeseed, soybean, castor and from the seeds of plants grown for textile fibres, mainly cotton and flax. Furthermore oil-bearing fruits mostly from coconut palms (coconuts containing copra), walnut trees, oil palms (palm fruits and kernels), Jatropha curcas L. or purging nut (Euphorbiaceae) and olive trees (olive) are other source of biofuel[59]. Today, waste vegetable oils can also be used for the production of PPO or biodiesel, traditionally used as an animal feed component . They have the advantage of being a readily available waste product, though thorough cleaning is necessary to remove contaminants that would quickly block fuel filters or damage the engine fuel system [28].

Different species of vegetable oils have been used in CI engines during the years, although only a fraction of them have been used and investigated thoroughly. For an extensive and significant review of these ne can refer to [60].

In Table 1 several kinds of plant oils are reported that have been tried in diesel engines at some time or other. Biodiesel has been mainly produced from edible vegetable oils all over the world. More than 95\% of global biodiesel production is made from edible vegetable oils, however the rapidly growing world population and rising consumption of bio-fuels are increasing demand for both food and bio-fuels. Hence the production of biodiesel from different non-edible oilseed crops has been extensively investigated over the last few years[61]. An mess of different biospecies are being experimented so far as feedstock for biofules (see [62-65]) 
Table 1: examples of potential edible and non-edible plant oils for use in CI engines.[66]

Edible oil

Sunflower oil, Rapeseed oil, Rice bran oil, Soybean Jatropha oil, Karanji or Pongamia oil, Neem oil, oil, Coconut oil, Corn oil, Palm oil, Olive oil, Pistachio Palestine oil, Sesame seed oil, Peanut oil, Opium poppy oil, Safflower oil

\section{Non-edible oil} oil, Cottonseed oil, Linseed oil, Mahua oil, Deccan hemp oil, Kusum oil, Orange oil, Rubber seed oil

Table 2 shows the properties of 18 oils for which substantial data are available[66], [67].

Table 2: comparative properties of fossil diesel, edible and non-edible plant oils and biodiesels. ${ }^{\text {a }}$ at $38^{\circ} \mathrm{C}$, b at $40^{\circ} \mathrm{C}$, c at $37.8^{\circ} \mathrm{C}$. [66]

\begin{tabular}{|c|c|c|c|c|c|c|c|}
\hline \multirow{2}{*}{$\begin{array}{l}\begin{array}{l}\text { CI engine } \\
\text { fuel }\end{array} \\
\text { Common } \\
\text { name }\end{array}$} & \multicolumn{7}{|c|}{ Properties } \\
\hline & $\begin{array}{l}\text { Calorific } \\
\text { value } \\
{[\mathrm{kJ} / \mathrm{kg}]}\end{array}$ & $\begin{array}{l}\text { Density } \\
{\left[\mathrm{kg} / \mathrm{m}^{3}\right]}\end{array}$ & $\begin{array}{c}\text { Flash } \\
\text { point } \\
{\left[{ }^{\circ} \mathrm{C}\right]}\end{array}$ & $\begin{array}{c}\text { Pour } \\
\text { point } \\
{\left[{ }^{\circ} \mathrm{C}\right]}\end{array}$ & $\begin{array}{c}\text { Kinematic } \\
\text { viscosity at } \\
27^{\circ} \mathrm{C} \text { [cSt] }\end{array}$ & $\begin{array}{l}\text { Carbon } \\
\text { residues } \\
{[\% w / w]}\end{array}$ & $\begin{array}{c}\text { Cetane } \\
\text { number }\end{array}$ \\
\hline Diesel & 43.35 & 815 & $45-60$ & -6.70 & 4.30 & 0.03-0.1 & 47.00 \\
\hline $\begin{array}{l}\text { Sunflower } \\
\text { oil }\end{array}$ & 39.52 & 918 & 73 & -15.00 & 58.50 & 0.23 & 37.10 \\
\hline $\begin{array}{l}\text { Cottonseed } \\
\text { oil }\end{array}$ & 39.64 & 912 & 234 & -15.00 & 50.10 & 0.42 & 48.10 \\
\hline Soybean oil & 39.62 & 914 & 254 & -12.20 & 65.40 & 0.27 & 38.00 \\
\hline Peanut oil & 39.80 & 903 & 271 & -6.70 & 39.60 & 0.24 & 41.80 \\
\hline Corn oil & 37.82 & 915 & 277 & -40.00 & 46.30 & 0.24 & 37.60 \\
\hline $\begin{array}{l}\text { Opium } \\
\text { poppy oil }\end{array}$ & 38.92 & 921 & - & - & 56.10 & - & - \\
\hline $\begin{array}{l}\text { Rapeseed } \\
\text { oil }\end{array}$ & 37.62 & 914 & 246 & -31.7 & 39.20 & 0.30 & 37.60 \\
\hline $\begin{array}{l}\text { Sesame } \\
\text { seed oil }\end{array}$ & 39.30 & 913 & 260 & -9.40 & 35.50 & 0.25 & 40.20 \\
\hline Palm oil & 36.51 & 918 & 267 & -31.7 & $39.60^{b}$ & - & 42.00 \\
\hline Coconut oil & 35.80 & 915 & - & - & 31.59 & - & - \\
\hline Mahua oil & 38.86 & 900 & 238 & 15.00 & $37.18^{\mathrm{b}}$ & 0.42 & - \\
\hline $\begin{array}{l}\text { Rice bran } \\
\text { oil }\end{array}$ & 39.50 & 916 & - & - & $44.52^{\mathrm{b}}$ & - & - \\
\hline Jatropha oil & 39.77 & 918 & 240 & - & 49.90 & $0.20 / 0.44$ & 45.00 \\
\hline $\begin{array}{l}\text { Pongamia } \\
\text { oil }\end{array}$ & 34.00 & 912 & 263 & - & 37.12 & - & - \\
\hline Jojoba oil & 42.76 & 863 & 292 & 6.00 & $25.48^{b}$ & - & - \\
\hline $\begin{array}{l}\text { Rubber } \\
\text { seed oil }\end{array}$ & 37.50 & 922 & 198 & - & $39.91^{b}$ & - & 37 \\
\hline
\end{tabular}


As Table 2 shows, plant derived oils are a viable alternative to petroleum oil because of the similarity in their physical and chemical properties. Therefore, when biofuels are fed into diesel engines, they behave like analogous fuels in the combustion chamber, but on other hand they have the advantage of being biodegradable, non-toxic and, carbon dioxide neutral as they are of plant origin[68]. Blends of such oils should be also considered, indeed, from thermal efficiency point of view; this seems to be not so different from traditional petroleum derivated fuels ([69], [70]). Also an ongoing efflorescence of research are in process to find ever new and cheaper feedstocks for producing biofuels (see e.g., [71]). Still this is an open field of research, since several problems for combustion may persist: see, for instance, [72].

The quality of the oil is very important in order to guarantee the correct operation of the vehicles, in particular the injectors, piston rings and lubrication oil stability. As for today, the only available standard is the German standard DIN 51605 [28].

Biofuel oils deviations from the properties of fossil diesel are shown graphically in Figure 2.

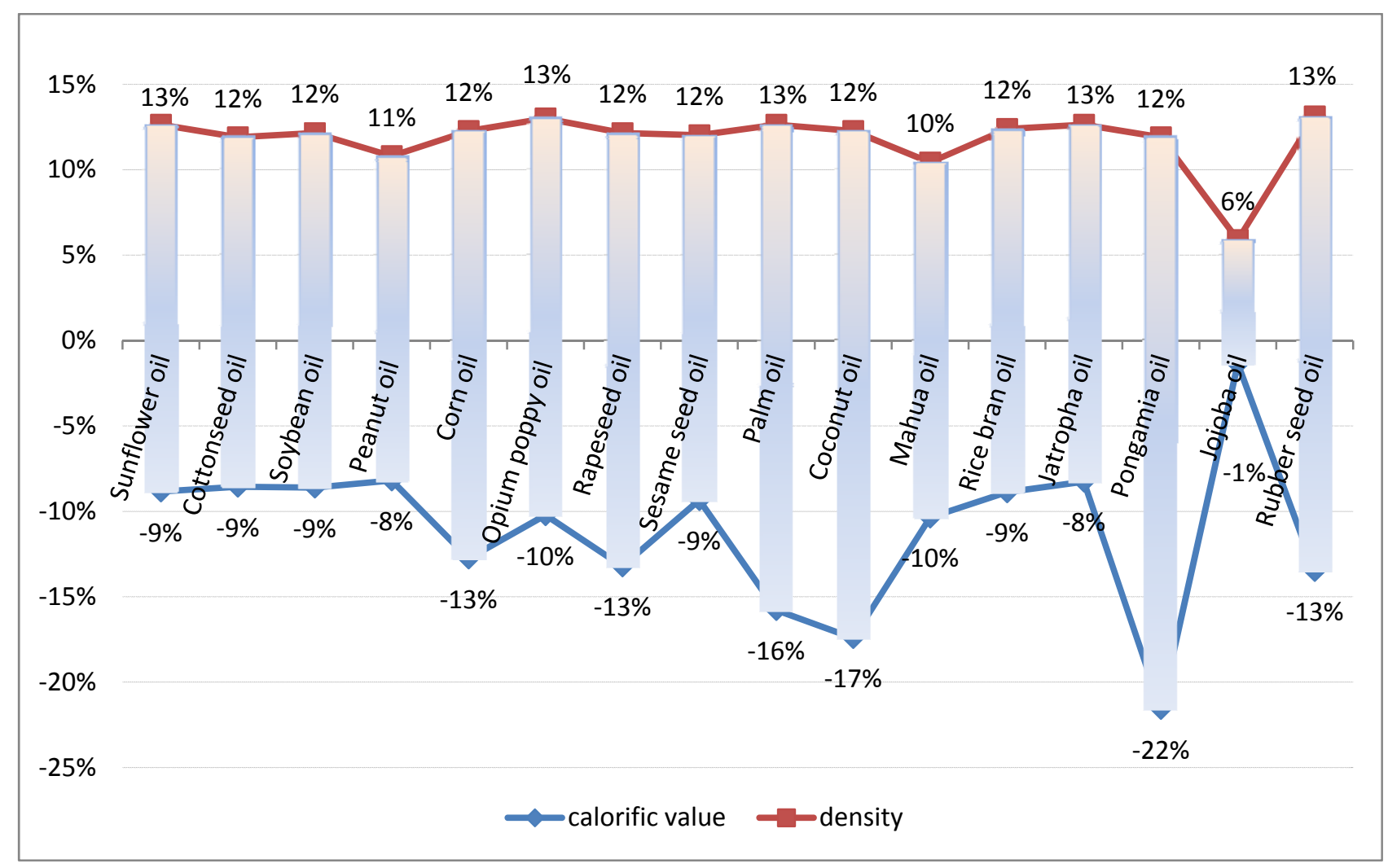




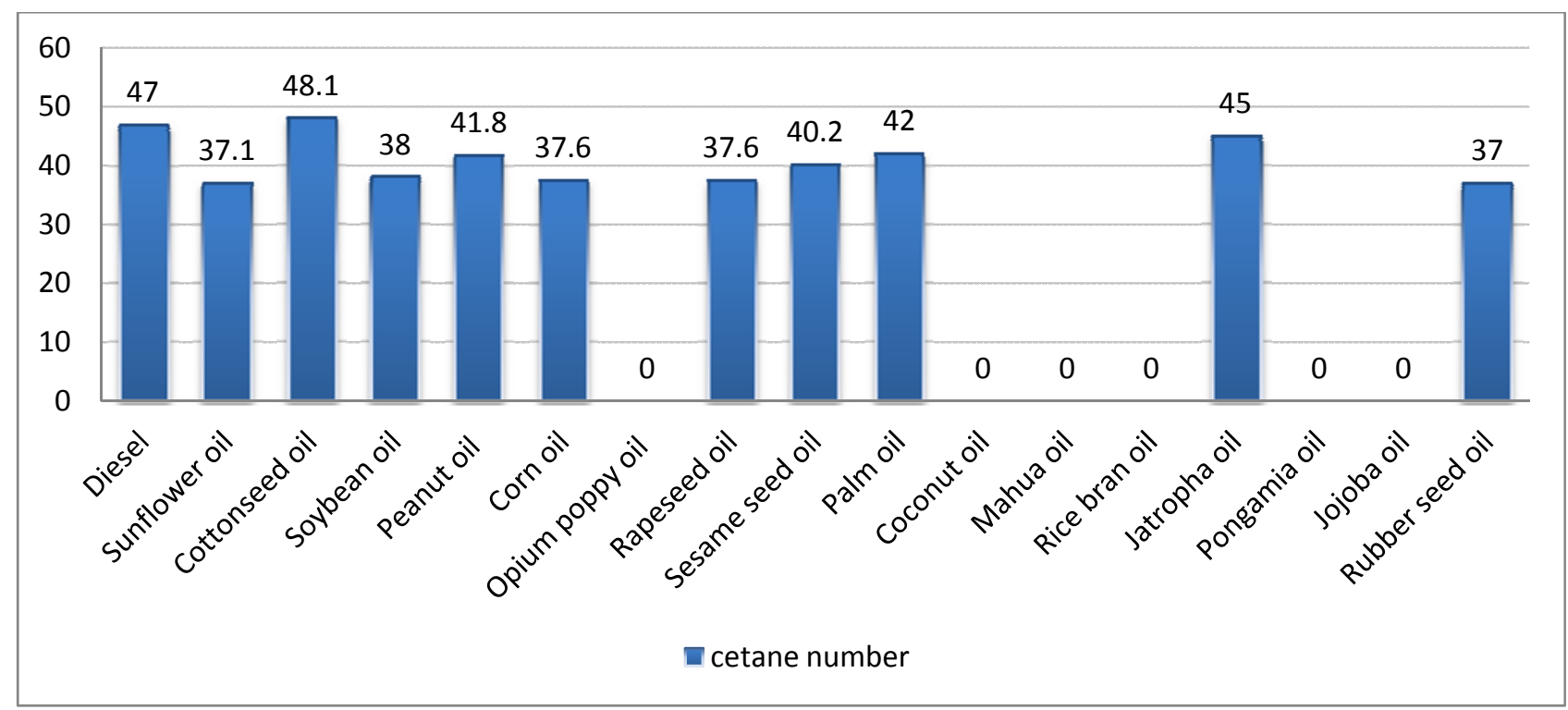

Fig. 2: Differences between plant oils properties and fossil diesel properties.

Vegetable oils have a higher density than diesel on an average of $12 \%$, but lower energy content with a calorific value around $10 \%$ inferior.

Cetane number is a measure of the ignition quality of a diesel fuel, i.e. the fuel's readiness to ignite. Fuels with a high Cetane number will have short ignition delays which correspond to greater efficiency; contrarily engines started with a low Cetane number fuel may suffer from engine knock and blow white clouds of smoke during engine ignition in severely cold weather. The Cetane number for most plant oils, it is around 10-20\% lower than that of fossil $\operatorname{diesel([59],~[61],~[66],~[67]).~}$

Kinematic viscosity and density are important characteristics to consider because they affect the fuel spray characteristics through flow resistance inside the injection system and in the nozzle holes [34] High viscosity causes poor fuel atomization during the spraying process, which in turn increases the engine coke deposits, demands more energy in order to pump the fuel and wears fuel pump elements and injectors[73]. For plant oils viscosity is higher and volatility lower than for fossil diesel.

Flash point temperature is the lowest temperature at which the vapour of a combustible liquid can be ignited in air. The flash point of vegetable oils is much higher than that of diesel. This makes its ignition relatively difficult, but its transportation and handling is much safer[74]. The Pour Point of a liquid is the lowest temperature at which it will pour or flow under prescribed conditions. Plant oils show an higher flash point temperature and lower pour point temperature in respect to fossil diesel.

The carbon residue value correlates with the carbonaceous deposits inside the combustion chamber and injector systems. Its formation is due to the way the fuel is injected and ignited in the diesel engine: when the fuel is injected, in the compression cycle, it is ignited spontaneously due to compression pressure and the air and fuel do not have a chance to mix thoroughly before ignition. The presence of fuel dense pockets, in the mixture, results in incomplete combustion of the fuel and the production of carbon soot or BC particulate 
matter[17]. In such incomplete combustion instances, the carbonaceous deposit for plant oils it is considerably higher than for fossil diesel[9].

\subsection{Effects on Engine Performance}

Several types of plant oils have been tried and compared in CI engines. Extensive literature is available on examining the performance variation obtained among using different types of plant oils and in some cases even with the same type of oil([66], [75], [76]). It is known that fuels with high viscosity cause several serious problems for engine performance and operation. To test the engine performance, variables like engine load, producer, speed, feedstock homogeneity, ambient conditions, injection type (direct or indirect), are the ones that mainly affect the results. Plant oil temperature is another key factor in the engine performance assessment. Nwafor [19] tested the shift in the performance of a diesel engine fed with vegetable oil inlet a different temperature, stating an improvement in the engine performance for temperatures higher than $55^{\circ} \mathrm{C}$. This is due to the viscosity-temperature relationship.

The brake power output of engines running on pure plant oils or blends varies in the range of $+10 \%$ to $-18 \%$ compared to engines running on fossil diesel under similar operating conditions. However, according to most reports there is a power decrease of around 2-18\% caused by (i) higher viscosity, which interferes with the injection process and leads to poor atomisation, leading in turn to incomplete combustion, some un-burnt plant oil and loss of power; and (ii) the low calorific value of plant oil [9]

The brake specific fuel consumption ${ }^{2}$ for plant oils and all blends is about $4-8 \%$ more than for fossil diesel. The higher specific fuel consumption may be due to lower calorific value and higher density of vegetable oils[20].

The brake thermal efficiency ${ }^{3}$ of pure plant oils and all blends change according to the engine load and speed([77], [78][79]). This variation is almost the same for diesel fuel though. In particular the b.t.e of vegetable oils is in the range of $3 \%$ more to $10 \%$ less than fossil diesel. The reasons for this may be the higher viscosity of the blends and lower volatility of vegetable oils. In a study [22] has been found that the slow burning of vegetable oils can be compensates starting the combustion earlier. Therefore, to obtain an higher brake thermal efficiency, it is sufficient to advance the injection timing.

\footnotetext{
2 is the mass rate of fuel consumption per unit brake power

3 is defined as the ratio between the brake power output and the energy of oil/fuel combustion
} 


\subsection{Effects on Exhaust emissions}

Results of several researches ([41], [66], [77], [79-85]) state that for CI engines operated on biofuels, emissions of $\mathrm{CO}$ and $\mathrm{NO}_{\mathrm{x}}$ were found to be higher, whereas unburned $\mathrm{HC}$ emissions were lower compared to fossil diesel.

The engine load strongly influences the emissions rate of vegetable oils. CO and HC emissions decrease as the load increases, although, on the other hand, this led to higher $\mathrm{NO}_{\mathrm{x}}$ emissions([81], [82]).

The correlation $\mathrm{CO}$ emissions-load engine is due to a better fuel/air equivalence ratio in case of heavy loads. In this case blending the vegetable oil with diesel could bring to a better performance, diminishing oil viscosity and poor spray atomization, key factors in exhaust emissions[23].

$\mathrm{NO}_{x}$ is produced during the combustion process, when nitrogen and oxygen are present at elevated temperatures. Due to higher combustion temperature in the engine cylinder, also $\mathrm{NO}_{\mathrm{x}}$ emissions increase as the engine load increases. Therefore the combustion temperature represent the main variable to regulate $\mathrm{NO}_{\mathrm{x}}$ emissions. It is important to highlight that most vegetable oils contain small quantities of nitrogen proteins, responsible of higher $\mathrm{NO}_{\mathrm{x}}$ emissions during the combustion respect to diesel fuel [24].

$\mathrm{NO}_{\mathrm{x}}$ is extremely dangerous since is 292 times more effective than $\mathrm{CO}$ in increasing greenhouse effect. Also in this case, blending the vegetable oils with other fuels represents a solution to decrease the $\mathrm{NO}_{\mathrm{x}}$ rate[20].

A better result was found for the unburned HC emissions, which are lower than diesel fuel. However this reduction is the largest at no-load and gets smaller as the load increases; the minimum rate of un-burnt HC emissions is reach at full engine load [24]

It has to be noted that results vary significantly according to the engine specifications, type, operating condition and vegetable oil used.

Possible solutions to decrease exhaust emissions are discussed further in the paper.

In Figure 3 are summarized the different exhaust emissions rates for different vegetable oils. 


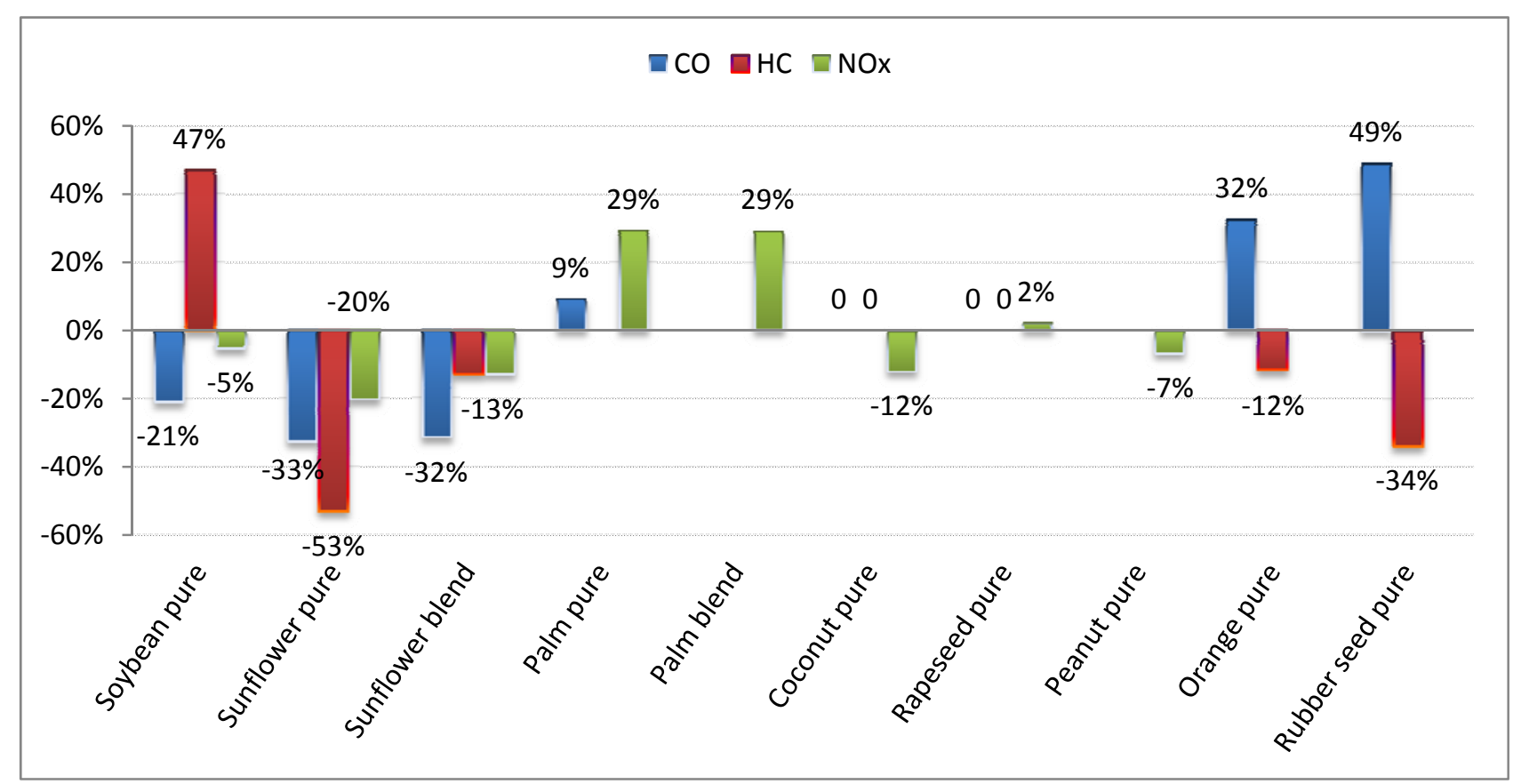

Fig. 3: CO, HC and NOx emission of CI engines running on plant oil (or blend with fossil diesel) as compared to fossil diesel[9].

CI engines running both on pure or blend sunflower oil have the best exhaust emissions performance. The most important gas to take into account is $\mathrm{NO}_{\mathrm{x}}$. Since it is more influent than $\mathrm{CO}$ in the global warming, its reduction does curry more relevance.

Rapeseed oil, the most cultivate crops in Europe, presents emissions rates almost equal to fossil diesel, when runs in CI engines.

Conclusively it can be stated that the particulate emissions reduction is more significant at low load. Vegetable oils present good performance as fuel, even though some engine problems were found in literature due to their higher viscosity and low volatility. Such problems are: carbon deposits on injector tip, piston rings and cylinder walls. Those problems bring up to another inconvenient: the dilution and thickening of the lubricating oil. Therefore using vegetable oil for long hours may led to choke the fuel filter causing break or failure of some mechanical members in the engine([53], [59], [81], [86]).

Overall the problems associated with plant oils usage in CI engines can be divided into durability problems and operational problems. The first ones include carbonization of injector tip and all the deposit formation. The second ones involve combustion and engine performance [25]

To face those difficulties various solutions have been proposed that concern engine modification or fuel modification. The engine modifications involve:

- Preheat vegetable oils before to starting up the engine,

- Adapt the injection system to vegetable oils viscosity,

- Dual fuelling the engine starting up with diesel oil and then switching to pure plant oil, 
- Exhaust gas recirculation (EGR) in the engine 4 .

The fuel modifications involve:

- Blend vegetable oil with biodiesel, ethanol or/and pure diesel,

- Transesterification, pyrolysis and emulsification of plant oil.

There are several studies ([52], [53], [66], [77], [84], [87], [88]) in which the fuel heating is investigated. It has been proved that preheating the vegetable oil assure a viscosity $80 \%$ lower than unheated oil, and similar to diesel fuel. Also carbon monoxide and dioxide production is almost the same for both heated and unheated oil at low loading conditions. Although at high engine load there is an higher $\mathrm{CO}_{2}$ emission of the heated fuel respect to the unheated and diesel fuel.

Therefore preheating vegetable oil is emission beneficial only at low speed and part-load operations.

Transesterification, pyrolysis and emulsification are process use during the biodiesel production, thus are not taking into account in this review, which is focused on pure plant oil usage.

Further, two valid systems to use straight vegetable oil as fuel are reported.

\section{PURE PLANT OIL USAGE IN DIESEL ENGINES}

Diesel engines are designed to burn diesel fuel, which has a lower viscosity than vegetable oil. Therefore the direct usage of pure plant oil in the engine leads to poor fuel atomisation and incomplete combustion, which can rapidly damage the engine. Pure vegetable oil thickness is the central problem for their use since it is 11 to 17 times thicker than conventional fuel. If the fuel is too thick it will not atomise properly when the fuel injectors spray it into the combustion chamber and it will not combust properly. Furthermore the injectors get coked up, leading to poor performance, higher exhaust emissions and reduced engine life([59], [80], [83], [88], [89]).

In CI engines the use of vegetable oils can be successfully achieved through fuel and engines modifications. A simple fuel modification can be obtained by blending the PPO with diesel or biodiesel; Modification of the injection system, fuel preheating and dual fuelling belong to engine adaptation. Heating [90-92] and blending [87], [93] of vegetable oils reduce the viscosity but its molecular structure remains unchanged in a polyunsaturated form and low volatility problems exist [30]

\footnotetext{
${ }^{4}$ Exhaust gas recirculation (EGR) is another approach to improving the exhaust gas emissions of plant oil fuelled engines. A small amount of exhaust gas is fed back into the cylinder, lowering peak temperatures and reducing the formation of $\mathrm{NO}_{\mathrm{x}}$
} 


\subsection{Generality}

Pure plant oil (PPO), also referred as PVO (Pure Vegetable Oil) or SVO (Straight Vegetable Oil), is the use of plant and vegetable oils without any modification to their chemical structure as a fuel to be combusted inside a diesel engine. This method should not be confused with biodiesel, which is a fuel derived from pure plant oils through a transesterification process that splits fatty acids from glycerine to reduce the viscosity of the pure plant oil similar to that of mineral diesel.

In Europe mostly rapeseed oil is used as PPO. In the German system of water pollution classes[38], rapeseed oil is classified in the lowest class 0 , whereas bio-diesel is in class 1 , and fossil diesel is in class 2 .

Unlike biodiesel, the use of PPO requires to modify the engine. The best way is to fit a professional kit to the diesel engine which includes replacement injectors and glow plugs optimised for vegetable oil, as well as fuel heating.

The engine modifications necessary to run a diesel engine with vegetable oils can be divided into two categories: one tank systems and two tank systems.

Both focus on plant oil viscosity and low volatility in order to avoid carbonaceous deposits, poor atomisation and incomplete combustion, with consequently damage engines and low engine performance. The viscosity is the main characteristic that has to be control, as PPO is about ten times more viscous than mineral diesel and trying to spray it through an injector designed for a fluid so much less viscous is similar to trying to spray butter through a washing up liquid bottle.

\subsection{Two-tank PPO systems}

With two-tank PPO kits one tank holds the vegetable oil and the other petro-diesel (or biodiesel).

The engine is started on the petro-diesel tank and runs on petro-diesel for the first few minutes while the vegetable oil is heated to lower the viscosity. Fuel heaters are electrical or use the engine coolant as a heat source. When the fuel reaches the required temperature, usually $70-80{ }^{\circ} \mathrm{C}\left(160-180{ }^{\circ} \mathrm{F}\right)$, the engine is switched over to the second tank and runs on PPO.
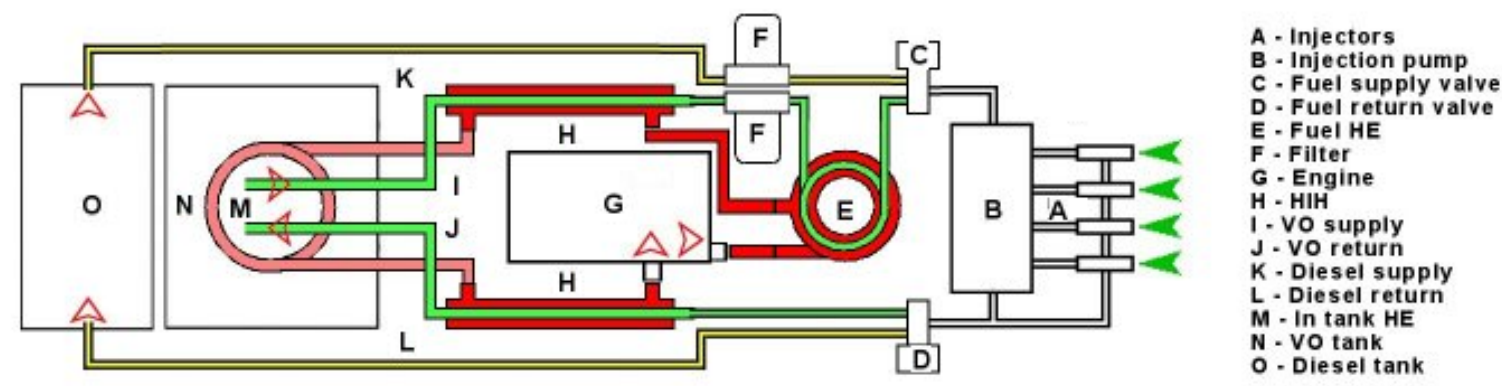

Fig. 4: illustration of a two tank system which allows a vehicle to run on PPO [39] 
Illustrated in Figure 4, is a two tank system for pure plant oil. Items " $\mathrm{O}$ " and "N" represent the two tanks, which are installed inside a vehicle. Vegetable oil in its un-transesterified form can also be used in diesel engines but it has to be heated, because modern engines are fitted with injection systems designed to deliver and properly atomise diesel fuel, which has a viscosity of approx. 8 centistokes. The example heating systems and peripherals in Figure 4 include "M" which is a heater located inside in the vegetable oil tank and "E" which is normally a special type of heat exchanger, that transfers heat to the engine cooling oil to the vegetable oil or in cruder systems glow plugs, using power from the battery to heat the oil.

Before the engine is shut down, it must be switched back to petro-diesel and the fuel system "purged" of vegetable oil before switching off, so that there is no cold vegetable oil left to coke up the injectors next time the engine is starting.

The operation of this system is that upon shut down of the engine the mineral diesel or biodiesel from the smaller tank " $O$ " is feed into the engine until all the vegetable oil is purged out. Upon start-up the engine is run on the mineral or bio-diesel until it reaches operational temperature and the rapeseed oil is once again feed to the engine.

Other important features of the system in Figure 4 include, " $F$ " which is a special type of filters especially PPO fuels such as rapeseed oil and " $B$ " which is an injector pump which has a slightly more robust design than normal engine pumps. In some cases the injectors " $\mathrm{A}$ " are also replaced but there is very little literature or detail on how exactly these injectors are modified and exactly the benefits of them.

One of the few scientific studies available found that vegetable oil must be heated to $150{ }^{\circ} \mathrm{C}$ $\left(302{ }^{\circ} \mathrm{F}\right)$ to achieve the same viscosity and fuel performance as petro-diesel: "Atomisation tests showed that at $150{ }^{\circ} \mathrm{C}$ the performance of the rapeseed oil is comparable with that of the diesel oil" [40]

That is double the temperature the two-tank PPO systems use. At only $70-80{ }^{\circ} \mathrm{C}$ vegetable oil is still much more viscous than petro-diesel (six times more viscous in the case of rapeseed oil, the oil specified in the German SVO fuel quality standard).

Whatever their technical merits and shortcomings, two-tank kits are better for longerdistance driving than for short stop-and-start trips[41].

\subsection{One-tank PPO systems}

With professional single-tank PPO systems there is no waiting or switching fuels as with twotank SVO kits, just start up and go, stop and switch off, like any other car.

The engine starts easily and burns cleanly from the start, even at sub-zero temperatures (supplementary heating is available for really cold conditions).

The "secret" is specially made injector nozzles, increased injection pressure and stronger glow-plugs, in addition to fuel pre-heating. 
Among the one-tank systems was taking into account the Elsbett conversion systems, who have more than 30 years at the forefront of using vegetable oil fuel in diesel engines.

With this system, there is no additional tank; all the fuel is held in the original tank of the vehicle. This solution relies on the adaptation of the injection process to the injection characteristics of vegetable oil, so typically, the glow-plugs, injectors, and injector mounts are modified.

The ELSBETT one-tank system can be fitted on pre-chamber diesels of most makes, as well as on TDI engines $(1,4 \mathrm{l}, 1,9 \mathrm{l}$ and $2,5 \mathrm{l})$ from the Volkswagen group (AUDI, SEAT, Skoda, Volkswagen and some Ford and VOLVO as well as 1.9 dTi motors from Renault)[52].

The typical one-tank conversion kit would contain the following parts:

- injector components

- additional fuel filter

- $\quad$ sometimes additional fuel pump

- coolant-water heat exchanger to pre-warm fuel

- electrical fuel heater/filter

- temperature switch

- fuel and water pipes

The cost of both systems, single and dual, are equals and around € 1000 [94], [95]

In the Scientific Laboratory of Biofuels at Latvia University of Agriculture were carried out some tests to verify the efficiency, in terms of consumption and emissions, of a diesel engine running just on rapeseed oil[53]. A VW Golf 1.9TD was opportunely modified using the ELSBETT one-tank system. The authors specify that the choice of one tank was made for facilities reasons, since the two tank would have required more space, and bureaucratic reasons, since the second fuel tank is classified as a modification, which requires a special certification.

The car was then tested along three different routes, in urban and suburban areas, comparing the engine performance before and after the conversion. The results show a slightly higher fuel consumption of rapeseed oil over fossil diesel, but significant savings against biodiesel fuel consumption. Moreover the authors pointed out that even after the car modification, it was still able to run on fossil diesel, with the only wariness of switching off the electric heating filter and the heat exchanger.

Surfing the home pages of Elsbett conversion kit manufacturer it is possible to find various examples of heavy and light duty vehicles fed with vegetable oil. In all the cases it has been highlighted that a great attention should be paid to the quality of oil used. A poor seed quality, processing and pressing can led to engine damage and bad performance. The lack of quality 
standard requirements or worldwide regulation for seed oils is still an issue that has to be solved ([59], [88], [96-98])

In Europe, only Germany set out a Quality Standard DIN 51605 for rapeseed oil (RKQualitätsstandard)[59].

\subsection{Performance of direct PPO use}

\subsubsection{Torque and power}

Many studies have been carried out to investigate the performance of vegetable oils in diesel engines, and mostly they present different results([22], [86], [87], [99-104]). A few of them display an approximate $10 \%$ drop in power when pure plan oil is used in CI engines instead of diesel oil[59], [93]. This lower performance has been addressed to the minor net calorific value of vegetable oils compared to diesel oil.

In a study on the performance of rapeseed oil blends by Nwafor and Rice [61] it is clearly found that the brake specific fuel consumption results were comparable with mineral diesel data.

The improvement in brake thermal efficiency when compared with that for mineral diesel fuel operation was higher than expected, indicating that the chemical energy of the vegetable oil was more effectively converted to mechanical work.

When operating on PPO, a diesel engine has more or less the same (thermal) efficiency as when operating on diesel. The volumetric energy content of pure vegetable oil is only $4 \%$ lower than for diesel. So overall the volumetric fuel consumption when operating on PPO can be a few $\%$ higher than for diesel.

\subsubsection{Hydrocarbon emissions}

Operations with pure rapeseed oil offered a net reduction in hydrocarbon emissions compared with mineral diesel results. The 50\% mineral diesel 50\% rapeseed oil blend competed favourably with the neat diesel fuel and they recommend rapeseed offers a reasonable substitute for diesel fuel.

Nwafor and Rice [61] in their study, proved that the rapeseed oil and blends with mineral diesel on average reduce the hydrocarbon emissions from the engine by at least $50 \%$ and even up to $75 \%$ at mid loads.

\subsubsection{Greenhouse gas emissions}

PPO emits a slightly higher amount of $\mathrm{CO}_{2}$ then regular fossil diesel per unit of energy. As the energy consumption with PPO is also about the same, the actual $\mathrm{CO}_{2}$ emitted from the vehicle is comparable. Though, the renewable aspect of vegetable oils feedstock make them more 
environmental friendly. The amount of emitted $\mathrm{CO}_{2}$ is, indeed, again adsorbed by the oil crops from which PPO is made. Theoretically, there could be a completely closed cycle, using exclusively renewable energy. However in practise fossil energy is still necessary during the agricultural process, the pressing process and in the distribution. Beyond that, the intensive use of fertilisers in agriculture is culpable for adding extra $\mathrm{N}_{2} \mathrm{O}$ emission in the atmosphere, which is a critical active gas for the global warming.

In general, it can be settled that the overall GHG savings coming from the use of biofuels over fossil fuels are on average estimated between 50 and 80\%, calculated without greenhouse gases related to land use change[66].

The literature is filled with lots of benefits for the fertility of the land and benefits for following crops and for $\mathrm{CO}_{2}$ absorption and neutrality of rapeseed oil. A study from Denmark[67] has calculated for a rapeseed oil crop that there is a reduction from the atmosphere of 14,937 tonnes per hectare suppression as against 1,604 for emissions. This would mean that $\mathrm{CO}_{2}$ reduction from the crop is 9.31 times greater than the gross $\mathrm{CO}_{2}$ emission.

\subsubsection{Specific fuel consumption}

In engine test the fuel consumption is measured as a mass flow rate per unit time second. The specific fuel consumption is the fuel flow rate per unit of power output and is a significant engine parameter. It measures how efficiently an engine is using the fuel supplied to produce work. Literature reviews show how specific consumption generally decreases with the increase in engine load. This is true for all fuels but is not valid with PPO, which displays an inferior reduction in consumption at low engine load than diesel oil in diesel engines given the higher volume consumption([68], [86], [101-103]). Regarding this point there is some contradiction in the literature, since some authors attested an overconsumption of approximately 8\% while others found out much lower (>5\%) results[20], [103], [105]. Overall, this higher specific fuel consumption value is addressed to the low Net Calorific Value of vegetable oils, together with their high density and high [7]

\subsubsection{Carbon monoxide emission}

Carbon monoxide concentrations in the exhaust is a measure of the combustion efficiency of the system. In some studies, $\mathrm{CO}$ emissions for vegetable oils are reported to be close to those of diesel fuel, when the vegetable oils are heated[104], [106]. Other reviews settled the amount of $\mathrm{CO}$ emissions according to the engine load, displaying a decreasing trend with a lower engine load. The minimum value in the CO emission is reached at around $75 \%$ of the maximum engine load. At that load, the difference is $31.6 \%$ [68]. The reason for this different performance is due to the poor combustion of vegetable oils according to the lower volatility 
and higher viscosity. Heterogeneity of the fuel richness in the cylinders and partial oxidation of hydrocarbons in the exhaust manifold are other two factors responsible for CO emission from diesel engine[34]. Other authors have found CO emissions for vegetable oils that were comparable to, if not less than, those of diesel oil, provided the vegetable oils were heated or the injection advance was adjusted. All the results attested the importance of the air/fuel mixture and good atomisation of the fuel in the carbon emission([52], [53], [101], [107]). 


\section{PURE PLANT OIL VS. BIODIESEL: SWOT ANALYSIS}

The well known advantages of biodiesel over PPO is that it works in diesel engines without needed any conversion or adaptation of the engine, which makes it more portable and "ready to use" in current diesel engines. What is not so highlighted is that pure vegetable oil is more environmentally friendly with regard to the energy balance as has been addressed by a Danish study[66] .

Originally, a SWOT Analysis is a strategic planning tool used to evaluate the Strengths, Weaknesses, Opportunities, and Threats involved in a business venture. In this case, the SWOT Analysis is applied to compare two similar but different types of biofuels: pure plant oil and biodiesel. They are both suitable for being used in compression ignition engines, and they both come from seed oils, nevertheless they have different production processes and then different properties.

The strength-weakness-opportunities-threat analysis of both vegetable oil was carried out based on literature reviews[67], [108-113]. The SWOT analysis outcomes are shown in the following tables.

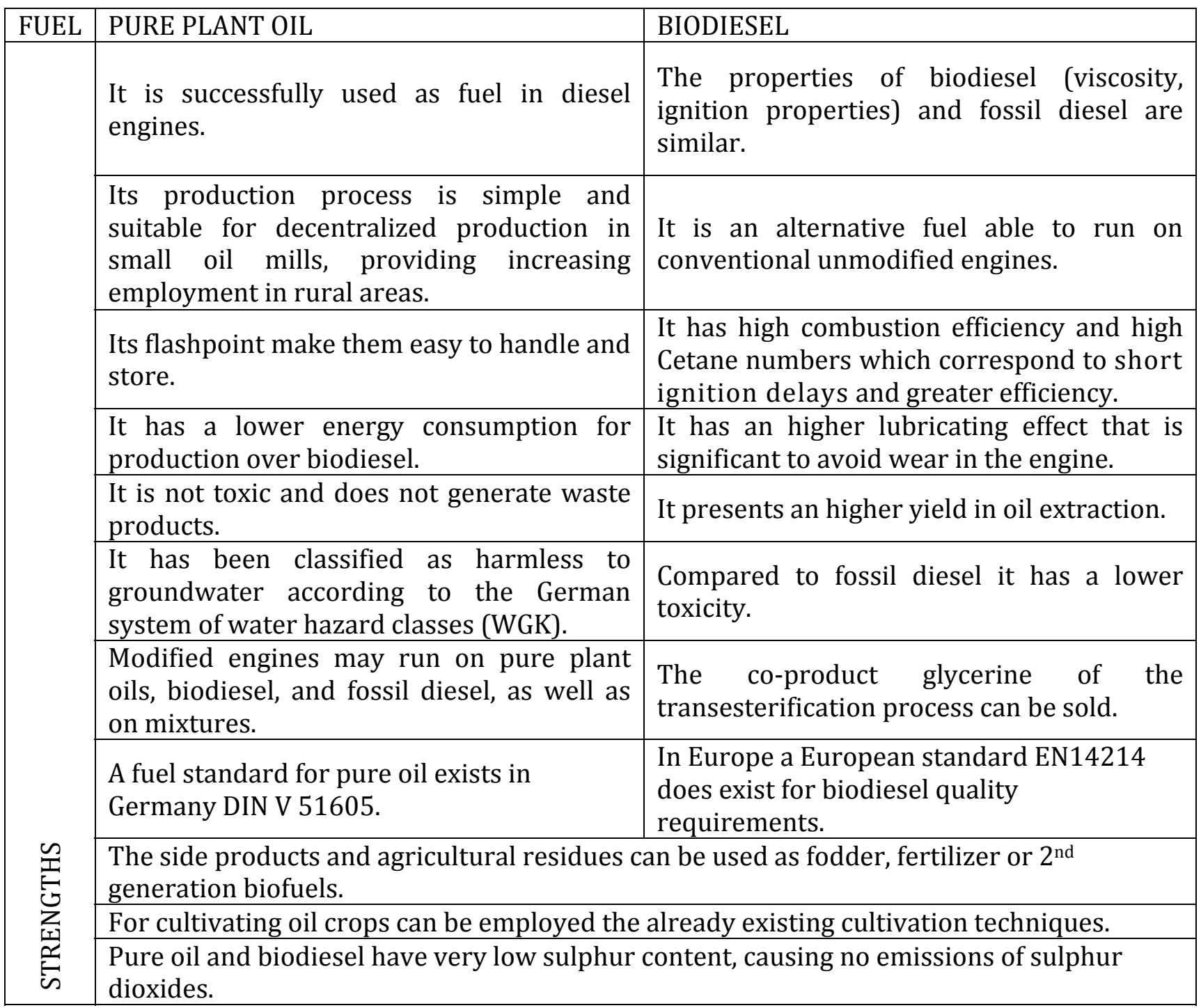




\begin{tabular}{|c|c|c|}
\hline FUEL & PURE PLANT OIL & BIODIESEL \\
\hline \multirow{7}{*}{ 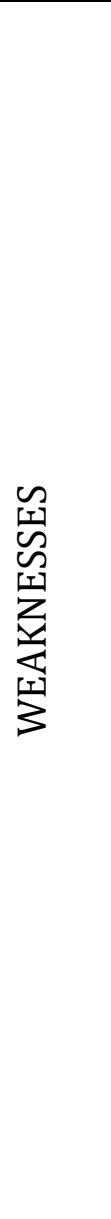 } & $\begin{array}{l}\text { It has very high viscosity and low } \\
\text { volatility which can led to poor } \\
\text { atomisation and lower engine } \\
\text { performance. }\end{array}$ & $\begin{array}{l}\text { It has an higher energy consumption for } \\
\text { production, that is twice the amount need } \\
\text { for pure plant oil and fossil diesel. }\end{array}$ \\
\hline & $\begin{array}{l}\text { It has a lower calorific value respect to } \\
\text { biodiesel and fossil diesel, which means } \\
\text { lower energy content, thus lower brake } \\
\text { thermal efficiency and higher specific fuel } \\
\text { consumption. }\end{array}$ & $\begin{array}{l}\text { It needs a refinery process that is not } \\
\text { suitable for decentralized production, } \\
\text { thus it cannot be performed in } \\
\text { agricultural economy, bringing to a less } \\
\text { employment in rural areas. }\end{array}$ \\
\hline & It needs a market development. & $\begin{array}{l}\text { It has an higher costs for establishment } \\
\text { and operation of production plants. }\end{array}$ \\
\hline & $\begin{array}{l}\text { Economic viability depends on seed yields } \\
\text { and income from by-products (press } \\
\text { cake). }\end{array}$ & $\begin{array}{l}\text { Economic viability strongly depends on } \\
\text { seed yields and income from by products } \\
\text { (glycerine and press cakes). }\end{array}$ \\
\hline & $\begin{array}{l}\text { In Europe no common standard for pure } \\
\text { oil exists. }\end{array}$ & $\begin{array}{l}\text { It is aggressive with fuel pipes, sealings } \\
\text { and filters, that have to be adapted. }\end{array}$ \\
\hline & & $\begin{array}{l}\text { Non modified engines may run on } \\
\text { biodiesel, and fossil diesel, as well as on } \\
\text { mixtures, but not on pure plant oils. }\end{array}$ \\
\hline & \multicolumn{2}{|c|}{$\begin{array}{l}\text { Long term storage of pure plant oil and biodiesel may cause degradations in certain } \\
\text { fuel properties, requiring additives. }\end{array}$} \\
\hline
\end{tabular}

\begin{tabular}{|l|l|l|}
\hline FUEL & \multicolumn{1}{|c|}{ PURE PLANT OIL } & \multicolumn{1}{|c|}{ BIODIESEL } \\
\hline \multirow{4}{*}{$\begin{array}{l}\text { It has a cheaper production process being } \\
\text { only produced by pressing and filtering } \\
\text { the oil seeds. }\end{array}$} & $\begin{array}{l}\text { Currently it is the dominant biofuel in the } \\
\text { Europe. }\end{array}$ \\
\cline { 2 - 3 } & $\begin{array}{l}\text { It does not generate co-products such as } \\
\text { glycerol and allows close cycle use of raw } \\
\text { materials and products in the same }\end{array}$ & $\begin{array}{l}\text { It is a portability, ready available fuel that } \\
\text { can directly feed CI engines. }\end{array}$ \\
\cline { 2 - 2 } & $\begin{array}{l}\text { Energy policy that provides tax reductions/exemptions and biofuel obligations could } \\
\text { largely increase use of pure plant oil and biodiesel. }\end{array}$ \\
\cline { 2 - 3 } & $\begin{array}{l}\text { Their use and development can realized energy supply security leading to strengthen } \\
\text { EU economy. }\end{array}$ \\
\cline { 2 - 3 } & Waste oil can be used as cheap feedstock for pure oil and biodiesel. \\
\cline { 2 - 3 } & Other oil plants than rape seed can be cultivated in Europe (e.g. sun flower, soy5). \\
\hline
\end{tabular}

\footnotetext{
${ }^{5}$ Also vehicles are being produced that run solely on these fuels.
} 


\begin{tabular}{|l|l|l|}
\hline FUEL & \multicolumn{1}{|c|}{ PURE PLANT OIL } & \multicolumn{1}{c|}{ BIODIESEL } \\
\hline \multirow{3}{*}{$\begin{array}{l}\text { It is necessary to adapt the engine to the } \\
\text { oil fuel, thus well-built vehicle } \\
\text { modifications have to be made. }\end{array}$} & $\begin{array}{l}\text { It is toxic and polluting in case of } \\
\text { spillage and percolation since contains } \\
\text { solvents and other chemical additives. }\end{array}$ \\
\cline { 2 - 3 } & $\begin{array}{l}\text { An increasing market for biodiesel will } \\
\text { saturate the demand for glycerine and the } \\
\text { price for this co-product will decrease. }\end{array}$ \\
\cline { 2 - 3 } & $\begin{array}{l}\text { In Europe mainly rape seed is used as feedstock source. Rape seed can be cultivated } \\
\text { only every four years on the same field. }\end{array}$ \\
& $\begin{array}{l}\text { No standard for PPO or biodiesel feedstocks exists, which means the variation in } \\
\text { feedstock properties could vary for many different reasons. }\end{array}$ \\
\hline
\end{tabular}

As the tables above show the usage of vegetable oil in a compression ignition engine cannot be undervalued [23], [114], [115]. PPO an biodiesel have both the potential to reduce GHGs emissions and dependency on fossil diesel.

If biodiesel needs a refinery process to modify the vegetable oil properties, PPO needs engine modifications.

In Europe pure plant oils and biodiesel, are currently mainly produced from rape seed, although other feedstock types are suitable for using.

\section{LIFE CYCLE ANALYSIS}

The Life Cycle Assessment methodology is an useful tool used to address the environmental impacts coming from biofuels use.

The scientific literature is full of LCA studies on biofuels, which show differing results according to the different inputs used or the different boundaries taken for the analysis [38], [105], [116-126].

Two of the major strengths of biofuels are their carbon neutral characteristic and renewable aspect, while generating new income for farmer and providing security energy supply. In spite of this, the GHG savings coming from biofuel use, don't appear to be so considerable.

Results from several life cycle studies evidence some environmental impacts such as eutrophication, biodiversity an ecotoxicity brought out from the intense crop cultivation. Land transformation and availability is a crucial aspect that has to be taken into account in the full biofuel life cycle.

The use of plant oils as fuel for compression ignition engines and the life cycle analysis has been reviewed by Hossain and Davies (8). The two main indicators investigated by the authors during the life cycle assessment were: energy output-to-input ratio and GHG emissions. During their study the above mentioned authors compared pure plant oil against fossil diesel and biodiesel, breaking down the biofuel life cycle into five phases: feedstock production, feedstock transportation, fuel production, fuel transportation/distribution and end use (8). Part of their analysis is further reported and discussed. 
Environmental impacts arise all along the biofuel value chain: during the land transformation and cultivation, while using fertilisers and agrochemicals products, in the biofuel process production and then during its transportation and final use in cars[73]

In Figure 5 is represented a simple biofuel production chain.

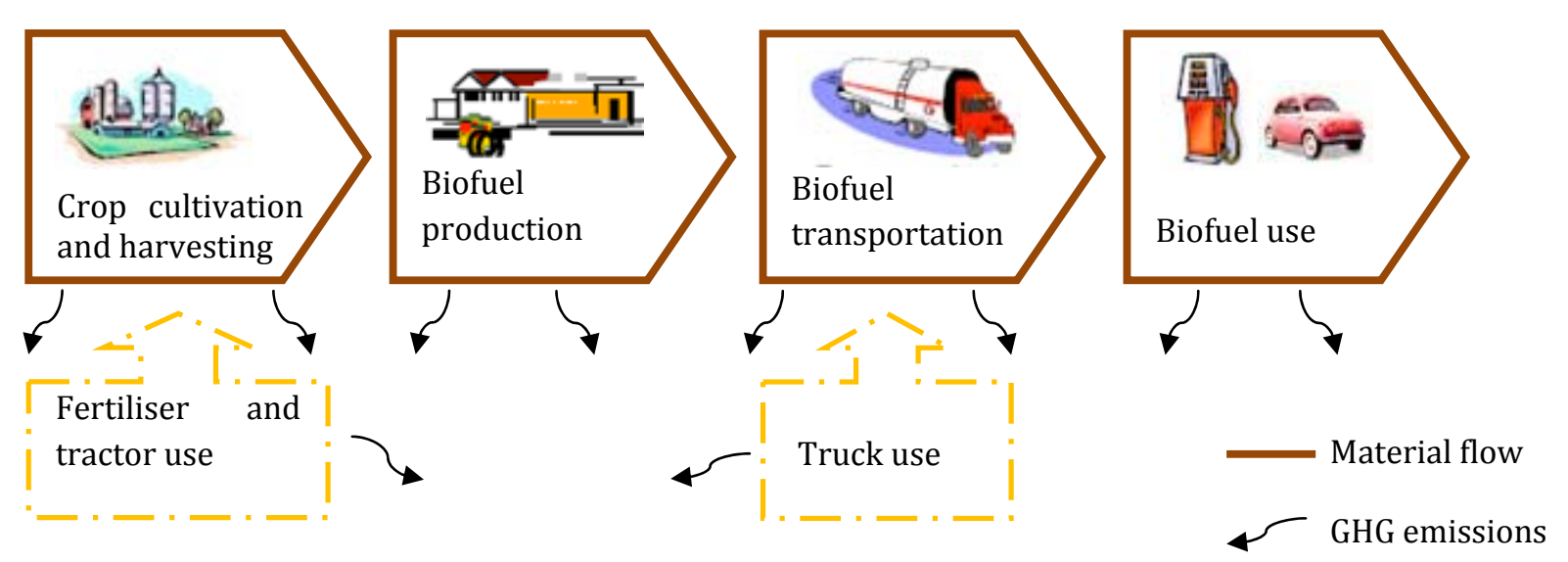

Fig. 5: Schematic biofuel production chain. The reference flow is one unit of biofuel use, i.e. 1 vehicle km. The major amount of pollutants is represented by $\mathrm{CO}_{2}$, which is generated in almost every unit process of the biofuel production chain.

A simple life cycle assessment is made up of a Life Cycle Inventory (LCI), necessary to quantify all relevant flows of materials and energy along the life cycle chain, and an environmental impact assessment, necessary to evaluate the impacts of those flows[73]

The materials flows vary a lot by the different authors. For example the amounts of fertilisers and pesticides used depend by the crop type, climate and environmental condition, country. According to the soil and seed type, land area and location, type and quantity of fertilisers, there will be generated different inventory analysis and environmental impact results.

Considering seed type, land location and type and quantity of fertilisers is possible identify some inventory categories and then the respective environmental impacts. For example, from the seed type and cultivation depend the energy inputs and ratio oil/press cake (inventory categories), but also the air pollution, water depletion, soil fertility, climate change (environmental impacts). The use of fertilisers and pesticides brings to heavy metal deposition on the soil, with consequently water pollution, eutrophication and ecotoxicity problems.

\subsection{Life cycle energy analysis}

For the life cycle analysis first of all it is necessary to determine the fossil energy ratio, defined as the ratio of final fuel product energy to the amount of fossil energy required to produce and distribute the fuel. Hassain and Davies [66] define the fossil energy ratio equal at $1.20 \mathrm{MJ}$, which is the total energy required for production of $1 \mathrm{MJ}$ of fossil diesel. This $1.20 \mathrm{MJ}$ fossil 
energy ratio corresponds to a life-cycle output-to-input energy ratio of 0.83 [127]. Has been measured that approximately $93 \%$ of the total primary energy requirement is used for crude oil extraction. The energy ratio for bio fuels depends on the plant oil specie and local climate conditions, type and efficiency of agricultural machineries, mode of transport and conversion processing technologies. Janulis [117] in his study settled that all energy ratios depend on climatic conditions and on the agro and processing technologies used. The life cycle energy balances vary when fuel is produced by the cold pressing and low productivity oil transesterification equipment and when fuel is produced by high productivity hot pressing and transesterification production technology. Application of more efficient oil extraction and transesterification technology increases energy efficiency indices substantially[117]. In the Hassain and Davies [66] study the energy ratios for fossil diesel, rapeseed oil and rapeseed biodiesel are reported as $0.88,3.2-3.5$ and 1.9 , respectively.

In Figure 6 are reported the results obtained from the above mentioned authors, during their life cycle analysis.

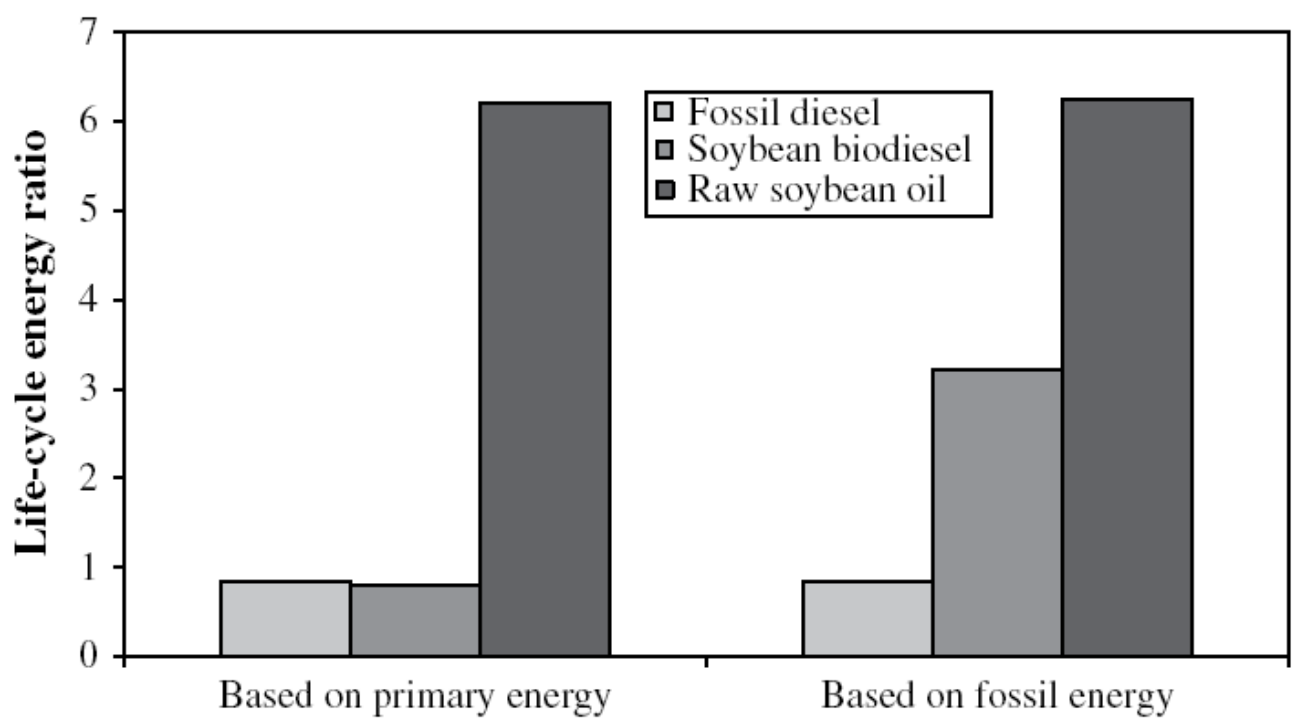

Fig. 6: Life cycle output to input energy ratio of fossil diesel, soybean biodiesel and raw soybean oil.[9]

It is clear that the use of pure plant oil (here soybean oil) in CI engines presents noticeable advantages respect to soybean biodiesel and fossil diesel related to input energy ratio.

\subsection{Life cycle GHG emission analysis}

GHGs emission come out along the entire biofuel production chain. All the literature reviews agree in stating that the environmentally most critical biofuel chain's process is crop cultivation. During this stage most of $\mathrm{CO}_{2}$ and $\mathrm{N}_{2} \mathrm{O}$ emissions are generated by land use and transformation.

To assess GHGs emission impact is used the Global Warming Potential (GWP) index. It has been created in the Kyoto Protocol to measure the potential of gases or volatile liquids to heat 
up the atmosphere. Due to the extremely low heat conductivity of the GHGs when released they traps heat in the atmosphere.

Therefore, GWP index is used to translate the level of emissions of various gases into a common measure, to compare the relative radiative forcing of different gases. It is calculated over a specific time interval, generally 100 or 500 years. GWP is expressed as a factor of carbon dioxide then called $\mathrm{CO}_{2}$ equivalents. In a 100 years time horizon, equivalence factors are[75]

- $1 \mathrm{~g} \mathrm{CO}_{2}=1 \mathrm{~g} \mathrm{CO}_{2}$-eq.

- $1 \mathrm{~g} \mathrm{CH}_{4}=23 \mathrm{~g} \mathrm{CO}_{2}$-eq.

- $1 \mathrm{~g} \mathrm{~N}_{2} \mathrm{O}=296 \mathrm{~g} \mathrm{CO}_{2}$-eq

Along this time horizon GWP resulting from emissions of $\mathrm{CO}_{2}, \mathrm{CH}_{4}$ and $\mathrm{N}_{2} \mathrm{O}$ are reported in Table 3.

Table 3: Global warming potential (GWP) and atmospheric lifetime. a 100 year time horizon. [76]

\begin{tabular}{|c|c|c|}
\hline $\mathrm{GHG}$ & Atmospheric lifetime (years) & GWP a \\
\hline $\mathrm{CO}_{2}$ & $50-200$ & 1 \\
\hline $\mathrm{CH}_{4}$ & $12 \pm 3$ & 21 \\
\hline $\mathrm{N}_{2} \mathrm{O}$ & 120 & 310 \\
\hline
\end{tabular}

The final index is calculated from the total GHGs, released all along the value chain, multiplied by the respective equivalence factors.

It is necessary to point out that, while pure plant oil biofuel does not need chemical processing to modify its viscosity, biodiesel does. The absence of the refinery step is translated into lower greenhouse gases emissions for straight vegetable oil.

Analysing the data in Table 4 can be noticed that biodiesel has higher GHG emission respect to fossil diesel and plant oil, during the life cycle. As pointed out in the second paragraph of the paper, biofuels do have more elevated $\mathrm{CO}_{2}$ and $\mathrm{NO}_{\mathrm{x}}$ emissions, but this amount is completely offset by the plantation of new oil bearing plants. Hence the released gases are then totally compensated over the plant oil life cycle.

Table 4: Life cycle GHG emission analysis of fossil diesel, raw soybean oil and soybean biodiesel.[9]

\begin{tabular}{|c|c|c|c|c|c|c|c|c|c|c|c|}
\hline \multirow{3}{*}{$\begin{array}{l}\text { GHG/ } \\
\text { pollutants }\end{array}$} & \multicolumn{11}{|c|}{ Life cycle air emission $(\mathrm{g} / \mathrm{kW} \mathrm{h})$} \\
\hline & \multicolumn{3}{|c|}{ Fossil diesel } & \multicolumn{6}{|c|}{ Plant oil (soybean) and/or biodiesel } & \multirow[b]{2}{*}{$\begin{array}{c}\text { Total } \\
\text { biodies } \\
\text { el }\end{array}$} & \multirow[b]{2}{*}{$\begin{array}{c}\text { Total } \\
\text { plant } \\
\text { oil }\end{array}$} \\
\hline & $\begin{array}{c}\text { Production, } \\
\text { refinery, } \\
\text { transport }\end{array}$ & $\begin{array}{c}\text { Diesel } \\
\text { tailpipe }\end{array}$ & Total & $\begin{array}{c}\text { Soybean } \\
\text { agricultur } \\
\text { e }\end{array}$ & $\begin{array}{c}\text { Soybean } \\
\text { crushing } \\
\text { /convers } \\
\text { ion }\end{array}$ & $\begin{array}{c}\text { Soybean } \\
\text { transport }\end{array}$ & $\begin{array}{l}\text { Biodiesel } \\
\text { transport }\end{array}$ & $\begin{array}{l}\text { Biodiesel } \\
\text { tailpipe }\end{array}$ & $\begin{array}{l}\text { Plant oil } \\
\text { tailpipe }\end{array}$ & & \\
\hline $\mathrm{CH}_{4}$ & 0.2718 & 0.0000 & 0.2718 & 0.0379 & 0.2231 & 0.0027 & 0.0011 & 0.0000 & 0.0000 & 0.2648 & 0.1285 \\
\hline $\mathrm{NO}_{\mathrm{X}}$ & 0.2795 & 6.4320 & 6.7115 & 0.2696 & 0.1994 & 0.1067 & 0.0289 & 7.0038 & 6.4320 & 7.6076 & 6.9246 \\
\hline $\mathrm{N}_{2} \mathrm{O}$ & 0.0091 & 0.0000 & 0.0091 & 0.0017 & 0.0007 & 0.0003 & 0.0003 & 0.0000 & 0.0000 & 0.0031 & 0.0028 \\
\hline $\mathrm{CO}$ & 0.0935 & 1.6080 & 1.7015 & 0.1834 & 0.0310 & 0.0150 & 0.0105 & 0.8646 & 1.2703 & 1.1145 & 1.5033 \\
\hline $\begin{array}{l}\mathrm{CO}_{2} \\
\text { (fossil) }\end{array}$ & 114.2 & 734.3 & 848.6 & & & 94.54 & 47.27 & 41.03 & 0.0000 & 182.8 & 94.54 \\
\hline $\begin{array}{l}\mathrm{CO}_{2} \\
\text { (biomass) }\end{array}$ & 0.0000 & 0.0000 & 0.0000 & & & 0.0000 & 0.0000 & 728.1 & 769.1 & 728.1 & 769.1 \\
\hline
\end{tabular}


Moreover $\mathrm{N}_{2} \mathrm{O}$ emissions are twice higher for fossil diesel than for plant oil. Nitrous oxide affects 293 times more GWP than $\mathrm{CO}_{2}$, therefore its reduction carries more importance in the operation of a CI [20], [75]

The results obtained by Hassain and Davies [66] are graphically reported in Figure 7.

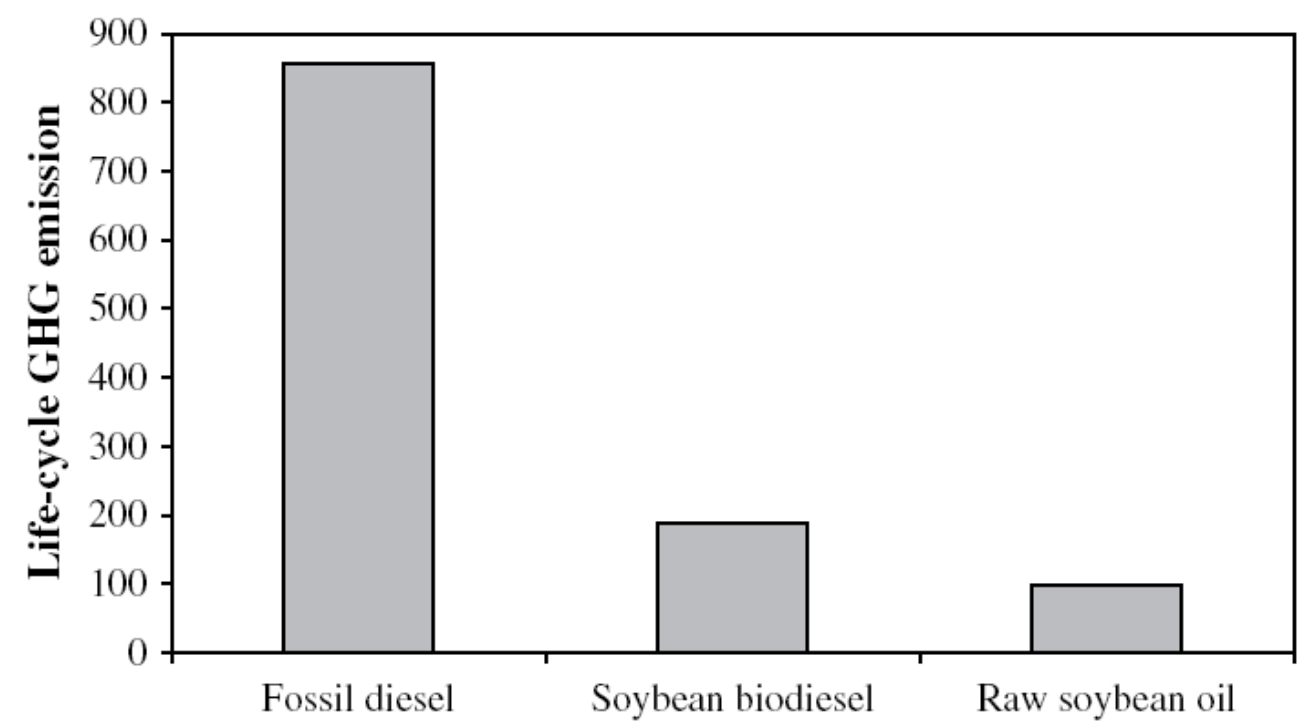

Fig. 7: the graph compares total life cycle GHG emission ( $\mathrm{g} \mathrm{CO}_{2}$ equivalent/kW $\mathrm{h}$ ) of fossil diesel, soybean biodiesel (100\%) and raw soybean oil. (8)

The life cycle assessment of biofuel for addressing GHG balance is complex.

By comparing Hassain and Davies [66] study with the results from different life cycle analysis it has to be noticed that the outcomes are not as positive as Hassain and Davies ones. It should be noted that some analysis indicate that some seed-based biofuels may actually increase lifecycle GHG emissions (substantially) respect to petroleum-derived fuels[128].

Due to the large variation in data, inputs and boundary system is not possible to identify which life cycle analysis is more reliable. Certainly it can be stated that an high and ecologically sustainable biomass yields joint to an efficient plant oil conversion process to fuel, are essential parameters to reach higher GHGs savings.

\section{NET LAND REQUIREMENT FOR EU BIOFUELS}

The new European Union Directive goal is to achieve by 2020 a biofuels' usage target of $10 \%$ in transport[80]. To meet this target between 18.5 and 21.1 millions of hectares are needed[90].

Biofuels can be made from anything that is, or ever was, a plant. First-generation biofuels derive from biomass. Applying different technologies the feed stocks (food and feed crops) are 
converted into biofuels. Since global population growth and an ever increasing demand for land for food supply in the future can be expected there will be competition for land use in order to provide biofuels and maintain enough of and reasonably priced food. Consequently the full development of the biomass option requires a thorough analysis of possible consequences of a major shift in land use.

Therefore a series of studies [43], [99], [129-131] have been carried out to evaluate the land use requirements for biofuel production.

In a study carried out in China [77] a methodology for estimating water and land footprints ${ }^{6}$ was implemented. The water required for harvesting a unit of feedstock crop (CWR) was calculated as the rate between the seasonal water evapotranspiration $\left(\mathrm{m}^{3} / \mathrm{ha}\right)$ and the crop yield (kg/ha). Then, multiplying this value with the biofuel density and amount of feedstock necessary to yield a kg of biofuel (C), it is obtained the water footprints of a certain biofuel.

The land footprints is calculated as the rate between biofuel density times feedstock conversion ratio (C), and the crop yield.

Results show how the highest water and land footprints is due to soybean feedstock, followed by rapeseed. The important amount of lands and water needed points out that vegetable oils for usage in diesel engines are more suitable for a small scale production for self-supply in agricultural machinery. Other authors [79] highlighted that biofuels need major water footprints than fossil fuels, while fertilisers and other agrochemical products can pollute water bodies, which is an additional issues it must be taken in mind.

Another international study [99], [129] estimates the potential lands for biofuel production, classifying three different scenarios:

- a base scenario, in which it is assumed a modest increases in seed oils cultivation, according to the current trends;

- an environment oriented scenario, in which it is assumed a major use of lands, but assuring sustainable farming practices and biodiversity maintenance;

- an energy oriented scenario, in which it is assumed a considerable conversion in land use including pasture lands.

The research work distinguishes between food and feed areas, meaning feed stocks to population or animals use respectively.

To estimates those required areas a function of population number was taken into account, joint to per capita food consumption levels.

The land resources considered in the model were the European ones, with a total agricultural area that includes 164 million hectares of cultivated land and 76 million hectares of permanent grassland.

Figure 8 provides a schematic overview of the estimating process.

\footnotetext{
${ }^{6}$ Water footprint is a measure of the total volume of water needed to produce goods and services of a nation.
} 


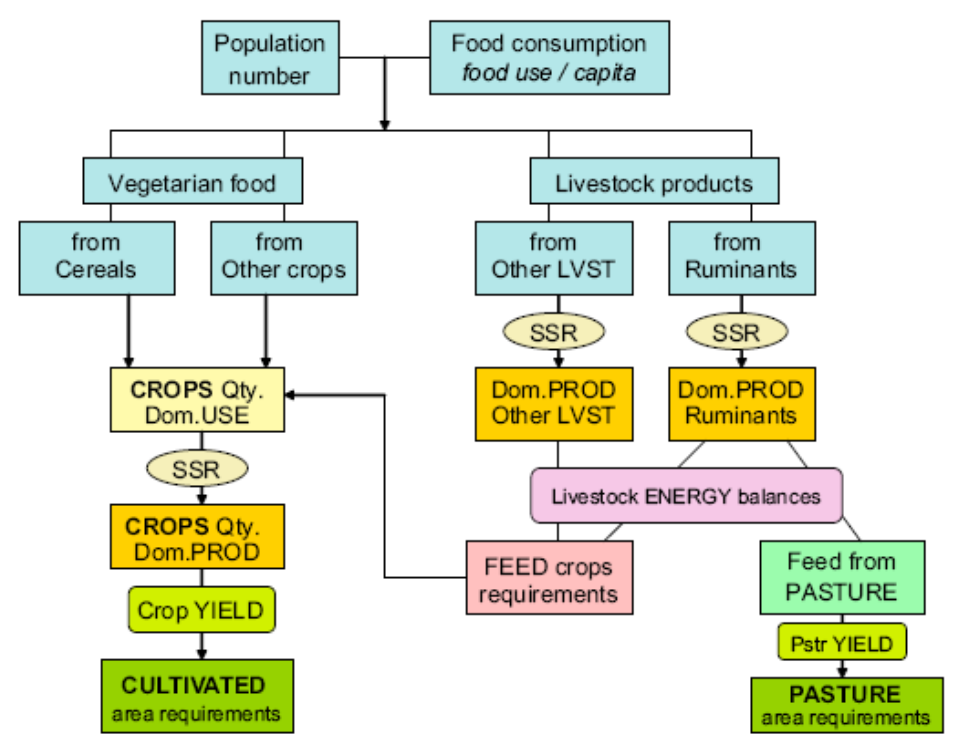

Fig. 8: Flow chart for food and feed area requirements calculation procedures. [81]

The study led to the conclusion that by 2030 some 22-46 million hectares of cultivated land could be used for bioenergy feedstock production.

The pasture land contemplated in the energy oriented scenario includes an extra 19 million hectares that could be used as feed stocks for second-generation biofuel production chains. Eastern Europe areas are found to be of noticeable interest, Ukraine's lands can be used to yield crops both for food and feed purpose.

Besides, also agricultural residues of food and feed crops may provide an additional source for biofuel production.

In a study carried on at Stuttgart University (Germany) [90]the opportunity of feeding animals with biofuel side products was investigated. The aim of the work was to find out if those residues were suitable for animal feed, in order to avoid further feed stock cultivation, diminishing the pressures on land area requirements. The utilization of biofuel side products tested with soy seeds in Brazil attested good results, led up to 7.1 million ha of land area savings.

In any case, the production rate of vegetable oils strongly depends on soil fertility, climate and local conditions, thus different regions are focusing their efforts on different types of oil - for example, Jatropha and Pongamia in India and Africa, rapeseed and sunflower in Europe, palm in Malaysia and Indonesia, and coconut oil in Philippines and Sri Lanka[9]

Regarding rapeseed oil, in a study performed for Elsbett Technologie are shown some of its strength points. As it is not grown in tropical regions it does not contribute to deforestation, but its rotation harvesting with cereals every four years helps to maintain long term food yields, lowering the competition with food cereals[82]

Together with edible-oils, also non-edible plant oils has been investigated in the last years. Their usage is particularly interesting as they are generally cheaper than edible-oils, but above all because they, apparently, do not compete with food[83]. The non-edible characteristics could be an advantage only if the land availability is enough for edible and inedible cultivations, and there will be kept a balance between both crop growing. Economic 
reasons could indeed bring farmers to switch from producing food crops to producing biofuels crops, even if they are non-edible. This situation will then create an unbalanced market condition, for which, if fewer farmers are producing food, the price of food will rise.

Furthermore the studies [43], [99], [129-131] pointed out the importance of $2^{\text {nd }}$ generation biofuel, on which is necessary to invest more resources in the next years. Lignocellulosic feed stocks plantations are indeed potentially important sources for biofuel production, thus the interest towards these biofuel is rapidly increasing.

\section{CONCLUSIONS}

As a summary from the state-of-the art analysis, amongst biofuels, PPOs can be used to replace diesel oil in CI engines, thanks to their similar physical and chemistry properties. Although their usage in diesel engines is subordinated to some engines modifications, due to their higher viscosity and lower volatility respect to fossil fuels. The most commonly used engine adaptation refers to the injection system and is successfully operated by several car manufacturers, the one presented in the paper was the Elsbett Technologie.

The benefits coming from the use of PPOs as fuel for diesel engines have been exposed and are here summarised:

- they are biodegradable and renewable fuel, thus they are environmentally friendly,

- compared to fossil fuel they have a lower sulphur content,

- they have flash point higher than that of diesel oil, thus are safer for use,

- $\mathrm{CO}_{2}$ emissions from diesel engines are absorbed by plants growth as feedstock for the following plant oil usage, reducing GHGs emissions,

- they are produced in rural areas and can contribute to the local economy,

- their agricultural residues from crops production can be used to feed animals or as potential source for $2^{\text {nd }}$ generation biofuel,

- they can improve security of energy supply, strengthening the national economy.

Besides this, with the actual knowledge technologies, the current rate of world fuels demand and the large land requirements for feedstock, plant oils are unlikely to substitute the majority of fossil diesel consumption.

Research is needed to increase productivity by species selection, optimisation of the biofuel production chain (building up a conversion system from feedstock to end products for example), engine modifications, on-farm processing technology, methods for maximising oil extraction, feed stock regulation.

The amount of biofuel production should be a trade-off between the need of land for food production and the need of land for industrial production, giving priority not to its market demand but to its production capacity.

As long as the technology to run vehicles will not change, PPOs offer an option to fossil fuel. They are good candidates to substitute a small to medium portion of petroleum, making a 
significant contribution as renewable fuel. Although a diversification in the energy sources is required to supply the worldwide fuel consumption.

They are an excellent solution in feeding agricultural machinery, since they can be directly produced locally in a short supply chain offering the extra fuel needed to enhance agricultural production. This is particularly important for developing countries and rural areas, because it will help to reduce the fossil fuel imports and balance the payments balance strengthening the local economy.

\section{REFERENCES}

[1] E. Commission and others, "Biofuels in the European Union: A vision for 2030 and beyond," Final report of the Biofuels Research Advisory Council, EUR, vol. 22066, 2006.

[2] S. Sorrell, R. Miller, R. Bentley, and J. Speirs, "Oil futures: A comparison of global supply forecasts," Energy Policy, vol. 38, no. 9, pp. 4990-5003, Sep. 2010.

[3] S. Sorrell, J. Speirs, R. Bentley, A. Brandt, and R. Miller, "Global oil depletion: A review of the evidence," Energy Policy, vol. 38, no. 9, pp. 5290-5295, Sep. 2010.

[4] M. Aftabuzzaman and E. Mazloumi, "Achieving sustainable urban transport mobility in post peak oil era," Transport Policy, vol. 18, no. 5, pp. 695-702, Sep. 2011.

[5] P. de Almeida and P. D. Silva, "The peak of oil production-Timings and market recognition," Energy Policy, vol. 37, no. 4, pp. 1267-1276, Apr. 2009.

[6] C. F. Curtis, "Peak globalization: Climate change, oil depletion and global trade," Ecological Economics, vol. 69, no. 2, pp. 427-434, Dec. 2009.

[7] A. Verbruggen and M. Al Marchohi, "Views on peak oil and its relation to climate change policy," Energy Policy, vol. 38, no. 10, pp. 5572-5581, Oct. 2010.

[8] Q. Y. Meng and R. W. Bentley, "Global oil peaking: Responding to the case for 'abundant supplies of oil'," Energy, vol. 33, no. 8, pp. 1179-1184, Aug. 2008.

[9] M. G. Salameh, "Can renewable and unconventional energy sources bridge the global energy gap in the 21 st century?," vol. 75, no. 1-2, pp. 33-42, 2003.

[10] A. P. C. Faaij and H. M. Londo, "A roadmap for biofuels...," Biomass \& Bioenergy, vol. in press, pp. 1-2.

[11] D. Puppàn, "Environmental evaluation of biofuels," Periodica Poltytechnica Ser. Soc. Man. Sci., vol. 10, no. 1, pp. 95-116, 2001.

[12] M. Kozak, "Effectiveness of Financial Support in European Union Countries in Terms of," 2009.

[13] M. Balat, "An Overview of Biofuels and Policies in the European Union," Energy Sources, Part B: Economics, Planning, and Policy, vol. 2, no. 2, pp. 167-181, 2007.

[14] D. A. Walker, "Biofuels, facts, fantasy, and feasibility," Journal of Applied Phycology, vol. 21, no. 5, pp. 509-517, Jun. 2009.

[15] L. Tao and A. Aden, "The economics of current and future biofuels," In Vitro Cellular \& Developmental Biology - Plant, vol. 45, no. 3, pp. 199-217, May 2009.

[16] R. Berthiaume, C. Bouchard, and M. A. Rosen, "Exergetic evaluation of the renewability of a biofuel," Exergy, An International Journal, vol. 1, no. 4, pp. 256-268, 2001.

[17] D. Demirbas A., "Biofuels sources, biofuel policy, biofuel economy and global biofuel projections," Energy Conversion and Management, vol. 49, no. 8, pp. 2106-2116, Aug. 2008.

[18] BRD, "National Biofuels Action Plan." Biomass Research and Development Board, 2008.

[19] J. J. Swanson, J. R. Sweeney, C. Larson, D. B. Kittelson, R. A. Newman, and R.P. Ziebarth, "Simultaneous Reduction of NOx, Solid, and Semi-Volatile Particles Using 4-Way Catalyzed Filtration Systems." AIChE. 
[20] A. Murugesan, C. Umarani, R. Subramanian, and N. Nedunchezhian, "Bio-diesel as an alternative fuel for diesel engines-A review," Renewable and Sustainable Energy Reviews, vol. 13, no. 3, pp. 653-662, Apr. 2009.

[21] G. Cebrat, A. Karagiannidis, and A. Papadopoulos, "Proposing intelligent alternative propulsion concepts contributing to higher $\mathrm{CO}<\mathrm{DN}>2</ \mathrm{DN}>$ savings with first generation biofuels," Management of Environmental Quality: An International Journal, vol. 19, no. 6, pp. 740749, Sep. 2008.

[22] G. Knothe, R. O. Dunn, and M. O. Bagby, "Biodiesel: the use of vegetable oils and their derivatives as alternative diesel fuels," U.S. Department of Agriculture, National Center for Agricultural Utilization Research, Peoria, IL 61604, 2003.

[23] Demirbas A., "Political, economic and environmental impacts of biofuels: A review," Applied Energy, vol. 86, Supplement 1, no. 0, p. S108-S117, Nov. 2009.

[24] J.-C. Bureau, A.-C. Disdier, C. Gauroy, and D. Tréguer, "A quantitative assessment of the determinants of the net energy value of biofuels," Energy Policy, vol. 38, no. 5, pp. 2282-2290, May 2010.

[25] P. S. Nigam and A. Singh, "Production of liquid biofuels from renewable resources," Progress in Energy and Combustion Science, vol. 37, no. 1, pp. 52-68, Feb. 2011.

[26] Trisha Gura, "Driving Biofuels from Field to Fuel Tank," Cell, vol. 138, no. 1, pp. 9-12, Jul. 2009.

[27] J. W. Ponton, "Biofuels: Thermodynamic sense and nonsense," Journal of Cleaner Production, vol. 17, no. 10, pp. 896-899, Jul. 2009.

[28] J. D. RUYCK,, J. M. JOSSART, G. PALMERS, D. LAVRIC, S. BRAM, A. NOVAK, M. S. REMACLE, G. DOOMS, C. HAMELINCK, and R. VAN DEN BROEK, Project CP/53 "Liquid biofuels in Belgium in a global bio-energy context."Belgium: Belgian Science Policy.

[29] A. A. Kiss, A. C. Dimian, and G. Rothenberg, "Solid Acid Catalysts for Biodiesel Production --Towards Sustainable Energy," Advanced Synthesis \& Catalysis, vol. 348, no. 1-2, pp. 75-81, Jan. 2006.

[30] Demirbas A., Biodiesel: a realistic fuel alternative for diesel engines. Springer, 2008.

[31] D. Antoni, Vladimir V. Zverlov, and Wolfgang H. Schwarz, "Biofuels from microbes," Appl Microbiol Biotechnol, vol. 77, pp. 23-35.

[32] J. Goldemberg and P. Guardabassi, "Are biofuels a feasible option?," Energy Policy, vol. 37, no. 1, pp. 10-14, Jan. 2009.

[33] C. Kiwjaroun, C. Tubtimdee, and P. Piumsomboon, "LCA studies comparing biodiesel synthesized by conventional and supercritical methanol methods," Journal of Cleaner Production, vol. 17, no. 2, pp. 143-153, Jan. 2009.

[34] G. E. Totten, S. R. Westbrook, and R. J. Shah, Fuels and lubricants handbook: technology, properties, performance, and testing. ASTM International, 2003.

[35] J. T. Kloprogge, L. V. Duong, and R. L. Frost, "A review of the synthesis and characterisation of pillared clays and related porous materials for cracking of vegetable oils to produce biofuels," Environmental Geology, vol. 47, no. 7, pp. 967-981, Mar. 2005.

[36] F. Karaosmanoğlu, E. Tetik, and E. Göllü, "Biofuel production using slow pyrolysis of the straw and stalk of the rapeseed plant," Fuel Processing Technology, vol. 59, no. 1, pp. 1-12, Apr. 1999.

[37] E. Poitrat, "The potential of liquid biofuels in France," Renewable Energy, vol. 16, no. 1-4, pp. 1084-1089, Apr. 1999.

[38] G. P. Hammond, S. Kallu, and M. C. McManus, "Development of biofuels for the UK automotive market," Applied Energy, vol. 85, no. 6, pp. 506-515, Jun. 2008.

[39] M. Farahani, D. J. Y. S. Pagé, and M. P. Turingia, "Sedimentation in biodiesel and Ultra Low Sulfur Diesel Fuel blends," Fuel, vol. 90, no. 3, pp. 951-957, Mar. 2011.

[40] Demirbas A, "Competitive liquid biofuels from biomass," Applied Energy, vol. 88, no. 1, pp. 17-28, Jan. 2011. 
[41] M. Lapuerta, O. Armas, R. Ballesteros, and J. Fernández, "Diesel emissions from biofuels derived from Spanish potential vegetable oils," Fuel, vol. 84, no. 6, pp. 773-780, Apr. 2005.

[42] G. Taylor, "Biofuels and the biorefinery concept," Energy Policy, vol. 36, no. 12, pp. 44064409, Dec. 2008.

[43] G. Fischer, S. Prieler, H. van Velthuizen, G. Berndes, A. Faaij, M. Londo, and M. de Wit, "Biofuel production potentials in Europe: Sustainable use of cultivated land and pastures, Part II: Land use scenarios," Biomass and Bioenergy, vol. 34, no. 2, pp. 173-187, Feb. 2010.

[44] T. Thamsiriroj and J. D. Murphy, "The impact of the life cycle analysis methodology on whether biodiesel produced from residues can meet the EU sustainability criteria for biofuel facilities constructed after 2017," Renewable Energy, vol. 36, no. 1, pp. 50-63, Jan. 2011.

[45] M. A. Keyzer, M. D. Merbis, and R. L. Voortman, "The Biofuel Controversy," De Economist, vol. 156, no. 4, pp. 507-527, Nov. 2008.

[46] M. Acaroğlu and H. Aydoğan, "Biofuels energy sources and future of biofuels energy in Turkey," Biomass and Bioenergy, vol. 36, no. 0, pp. 69-76, Jan. 2012.

[47] R. Pate, G. Klise, and B. Wu, "Resource demand implications for US algae biofuels production scale-up," Applied Energy, vol. 88, no. 10, pp. 3377-3388, Oct. 2011.

[48] L. Xu, D. W. F. (Wim) Brilman, J. A. M. Withag, G. Brem, and S. Kersten, "Assessment of a dry and a wet route for the production of biofuels from microalgae: Energy balance analysis," Bioresource Technology, vol. 102, no. 8, pp. 5113-5122, Apr. 2011.

[49] S. Bastianoni, F. Coppola, E. Tiezzi, A. Colacevich, F. Borghini, and S. Focardi, "Biofuel potential production from the Orbetello lagoon macroalgae: A comparison with sunflower feedstock," Biomass and Bioenergy, vol. 32, no. 7, pp. 619-628, Jul. 2008.

[50] J. Sheehan, V. Camobreco, J. Duffield, M. Graboski, and H. Shapouri, "An overview of biodiesel and petroleum diesel life cycles," Bioresource Technology, vol. 99, no. 10, pp. 3975-3981, 1998.

[51] A. P. Marchenko and V. G. Semenov, "ALTERNATIVE BIOFUEL FROM RAPE OIL DERIVATIVES," Chemistry and Technology of Fuels and Oils, vol. 37, no. 3, 2001.

[52] C. P. Sigar, S. L. Soni, J. Mathur, and D. Sharma, "Performance and Emission Characteristics of Vegetable Oil as Diesel Fuel Extender," Energy Sources, Part A: Recovery, Utilization, and Environmental Effects, vol. 31, no. 2, pp. 139-148, 2008.

[53] A. S. Ramadhas, S. Jayaraj, and C. Muraleedharan, "Characterization and effect of using rubber seed oil as fuel in the compression ignition engines," Renewable Energy, vol. 30, no. 5, pp. 795-803, Apr. 2005.

[54] V. R. Wiggers, H. F. Meier, A. Wisniewski Jr., A. A. Chivanga Barros, and M. R. Wolf Maciel, "Biofuels from continuous fast pyrolysis of soybean oil: A pilot plant study," Bioresource Technology, vol. 100, no. 24, pp. 6570-6577, Dec. 2009.

[55] A. A. Lappas, S. Bezergianni, and I. A. Vasalos, "Production of biofuels via co-processing in conventional refining processes," Catalysis Today, vol. 145, no. 1-2, pp. 55-62, Jul. 2009.

[56] P. Tamunaidu and S. Bhatia, "Catalytic cracking of palm oil for the production of biofuels: Optimization studies," Bioresource Technology, vol. 98, no. 18, pp. 3593-3601, Dec. 2007.

[57] L. T. H. Nam, T. Q. Vinh, N. T. T. Loan, V. D. S. Tho, X.-Y. Yang, and B.-L. Su, "Preparation of bio-fuels by catalytic cracking reaction of vegetable oil sludge," Fuel, vol. 90, no. 3, pp. 1069-1075, Mar. 2011.

[58] T. L. Chew and S. Bhatia, "Catalytic processes towards the production of biofuels in a palm oil and oil palm biomass-based biorefinery," Bioresource Technology, vol. 99, no. 17, pp. 79117922, Nov. 2008.

[59] S. S. Sidibé, J. Blin, G. Vaitilingom, and Y. Azoumah, "Use of crude filtered vegetable oil as a fuel in diesel engines state of the art: Literature review," Renewable and Sustainable Energy Reviews, vol. 14, no. 9, pp. 2748-2759, Dec. 2010.

[60] J. Gressel, "Transgenics are imperative for biofuel crops," Plant Science, vol. 174, no. 3, pp. 246-263, Mar. 2008. 
[61] M. Balat and H. Balat, "Progress in biodiesel processing," Applied Energy, vol. 87, no. 6, pp. 1815-1835, Jun. 2010.

[62] G. N. Jham, B. R. Moser, S. N. Shah, R. A. Holser, O. D. Dhingra, S. F. Vaughn, M. A. Berhow, J. K. Winkler-Moser, T. A. Isbell, R. K. Holloway, E. L. Walter, R. Natalino, J. C. Anderson, and D. M. Stelly, "Wild Brazilian Mustard (Brassica juncea L.) Seed Oil Methyl Esters as Biodiesel Fuel," Journal of the American Oil Chemists' Society, vol. 86, no. 9, pp. 917-926, Jul. 2009.

[63] G. M. Gübitz, M. Mittelbach, and M. Trabi, "Exploitation of the tropical oil seed plant Jatropha curcas L.," Bioresource Technology, vol. 67, no. 1, pp. 73-82, Jan. 1999.

[64] C. R. Carvalho, W. R. Clarindo, M. M. Praça, F. S. Araújo, and N. Carels, "Genome size, base composition and karyotype of Jatropha curcas L., an important biofuel plant," Plant Science, vol. 174, no. 6, pp. 613-617, Jun. 2008.

[65] C. Chang-Hung, "Miscanthus plants used as an alternative biofuel material: The basic studies on ecology and molecular evolution," Renewable Energy, vol. 34, no. 8, pp. 1908-1912, Aug. 2009.

[66] A. K. Hossain and P. A. Davies, "Plant oils as fuels for compression ignition engines: A technical review and life-cycle analysis," Renewable Energy, vol. 35, no. 1, pp. 1-13, Jan. 2010.

[67] R. D. Misra and M. S. Murthy, "Straight vegetable oils usage in a compression ignition engine-A review," Renewable and Sustainable Energy Reviews, vol. 14, no. 9, pp. 3005-3013, Dec. 2010.

[68] D. Agarwal and A. K. Agarwal, "Performance and emissions characteristics of Jatropha oil (preheated and blends) in a direct injection compression ignition engine," Applied Thermal Engineering, vol. 27, no. 13, pp. 2314-2323, Sep. 2007.

[69] L. Raslavičius and Ž. Bazaras, "Ecological assessment and economic feasibility to utilize first generation biofuels in cogeneration output cycle - The case of Lithuania," Energy, vol. 35, no. 9, pp. 3666-3673, Sep. 2010.

[70] M. Karabektas and M. Hosoz, "Performance and emission characteristics of a diesel engine using isobutanol-diesel fuel blends," Renewable Energy, vol. 34, no. 6, pp. 1554-1559, Jun. 2009.

[71] P. T. Scott, L. Pregelj, N. Chen, J. S. Hadler, M. A. Djordjevic, and P. M. Gresshoff, "Pongamia pinnata: An Untapped Resource for the Biofuels Industry of the Future," BioEnergy Research, vol. 1, no. 1, pp. 2-11, Feb. 2008.

[72] M. Kratzeisen and J. Müller, "Effect of fatty acid composition of soybean oil on deposit and performance of plant oil pressure stoves," Renewable Energy, vol. 34, no. 11, pp. 2461-2466, Nov. 2009.

[73] E. Alptekin and M. Canakci, "Determination of the density and the viscosities of biodieseldiesel fuel blends," Renewable Energy, vol. 33, no. 12, pp. 2623-2630, Dec. 2008.

[74] New York and Geneva, "The emerging biofuels market: regulatory, trade and development implications.," 2006.

[75] H. Hazar and H. Aydin, "Performance and emission evaluation of a CI engine fueled with preheated raw rapeseed oil (RRO)-diesel blends," Applied Energy, vol. 87, no. 3, pp. 786-790, Mar. 2010.

[76] G. M. Tashtoush, M. I. Al-Widyan, and A. M. Albatayneh, "Factorial analysis of diesel engine performance using different types of biofuels," Journal of Environmental Management, vol. 84, no. 4, pp. 401-411, Sep. 2007.

[77] C. Crookes, R.J., "Comparative bio-fuel performance in internal combustion engines," Biomass and Bioenergy, vol. 30, no. 5, pp. 461-468, May 2006.

[78] B. N. M. S. K. A. Ramesh, "An experimental comparison of methods to use methanol and Jatropha oil in a compression ignition engine," vol. 25, no. 3, pp. 309-318, 2003.

[79] J. Narayana Reddy and A. Ramesh, "Parametric studies for improving the performance of a Jatropha oil-fuelled compression ignition engine," Renewable Energy, vol. 31, no. 12, pp. 19942016, Oct. 2006. 
[80] R. D. Misra and M. S. Murthy, "Performance, emission and combustion evaluation of soapnut oil-diesel blends in a compression ignition engine," Fuel, vol. 90, no. 7, pp. 2514-2518, Jul. 2011.

[81] N. Yilmaz and B. Morton, "Comparative characteristics of compression ignited engines operating on biodiesel produced from waste vegetable oil," Biomass and Bioenergy, vol. 35, no. 5, pp. 2194-2199, May 2011.

[82] N. Yilmaz and B. Morton, "Effects of preheating vegetable oils on performance and emission characteristics of two diesel engines," Biomass and Bioenergy, vol. 35, no. 5, pp. 20282033, May 2011.

[83] S. Y. S. Y. No S.Y:, "Inedible vegetable oils and their derivatives for alternative diesel fuels in CI engines: A review," Renewable and Sustainable Energy Reviews, vol. 15, no. 1, pp. 131-149, 2011.

[84] B. S. Chauhan, N. Kumar, Y. Du Jun, and K. B. Lee, "Performance and emission study of preheated Jatropha oil on medium capacity diesel engine," Energy, vol. 35, no. 6, pp. 2484-2492, Jun. 2010.

[85] M. Senthil Kumar, A. Ramesh, and B. Nagalingam, "An experimental comparison of methods to use methanol and Jatropha oil in a compression ignition engine," Biomass and Bioenergy, vol. 25, no. 3, pp. 309-318, Sep. 2003.

[86] G. Vartilingom, G, "Utilisations énergétiques de l'huile de coton," Montpellier: Cahiers Agricultures, 2006.

[87] O. M. I. Nwafor and G. Rice, "Performance of rapeseed oil blends in a diesel engine," Applied Energy, vol. 54, no. 4, pp. 345-354, Aug. 1996.

[88] B. Grau, E. Bernat, R. Antoni, R. Jordi-Roger, and P. Rita, "Small-scale production of straight vegetable oil from rapeseed and its use as biofuel in the Spanish territory," Energy Policy, vol. 38, no. 1, pp. 189-196, Jan. 2010.

[89] D. Agarwal, L. Kumar, and A. K. Agarwal, "Performance evaluation of a vegetable oil fuelled compression ignition engine," Renewable Energy, vol. 33, no. 6, pp. 1147-1156, Jun. 2008.

[90] G. Labeckas and S. Slavinskas, "Comparative performance of direct injection diesel engine operating on ethanol, petrol and rapeseed oil blends," Energy Conversion and Management, vol. 50, no. 3, pp. 792-801, Mar. 2009.

[91] M. T. Bialkowski, T. Pekdemir, D. P. Towers, R. Reuben, M. Brautsch, and G. Elsbett., "Effect of fuel temperature and ambient pressure on a common rail rapeseed oil spray," Internal Combustion Engine, pp. 1-2, 2004.

[92] A. Bernardo, R. Howard-Hildige, A. O'Connell, R. Nichol, J. Ryan, B. Rice, E. Roche, and J. . Leahy, "Camelina oil as a fuel for diesel transport engines," Industrial Crops and Products, vol. 17, no. 3, pp. 191-197, May 2003.

[93] R. Altın, S. Çetinkaya, and H. S. Yücesu, "The potential of using vegetable oil fuels as fuel for diesel engines," Energy Conversion and Management, vol. 42, no. 5, pp. 529-538, Mar. 2001.

[94] Gotaverde, "Diesel engine adaptation." 14-Jun-2011.

[95] MEET, “Technical guidance for biofuels," Biofuel cities, Jun. 2011.

[96] G. B. I. Dukulis, A. Birkavs, G. Birzietis,, and V. Pirs, "Adaptingof automobile VW Golf for using pure rapeseed oil as fuel," Engineeering for rural development, vol. 52, no. 11, 2009.

[97] Usta N., Aydoğan, B. Aydoğan, A. H. Çon, E. Uğuzdoğan, and S.G. Özkal, "Properties and quality verification of biodiesel produced from tobacco seed oil," Energy Conversion and Management, vol. 52, no. 5, pp. 2031-2039, 2011.

[98] G. A. Pereyra-Irujo, N. G. Izquierdo, M. Covi, S. M. Nolasco, F. Quiroz, and L. A. N. Aguirrezábal, "Variability in sunflower oil quality for biodiesel production: A simulation study," Biomass and Bioenergy, vol. 33, no. 3, pp. 459-468, Mar. 2009.

[99] K. Agarwal, "Biofuels (alcohols and biodiesel) applications as fuels for internal combustion engines," Progress in Energy and Combustion Science, vol. 33, no. 3, pp. 233-271, Jun. 2007.

[100] National Bio-diesel Board., "Guidance on blends above B20." 16-Jan-2008. 
[101] A. K. Agarwal and K. Rajamanoharan, "Experimental investigations of performance and emissions of Karanja oil and its blends in a single cylinder agricultural diesel engine," Applied Energy, vol. 86, no. 1, pp. 106-112, Jan. 2009.

[102] T. Daho, "Contribution à l'étude des conditions optimales de combustion del huiles végétales dans les moteurs Diesel et sur les bruleurs: cas de l'huile de coton," Université de Ouagadougou, Thèse de doctorat : Sciences exactes et appliquées. Energétique/Combustion., 2008.

[103] Y. D. Wang, T. Al-Shemmeri, P. Eames, J. McMullan, N. Hewitt, Y. Huang, and S. Rezvani, "An experimental investigation of the performance and gaseous exhaust emissions of a diesel engine using blends of a vegetable oil," Applied Thermal Engineering, vol. 26, no. 14-15, pp. 1684-1691, Oct. 2006.

[104] S. Bari, T. H. Lim, and C. W. Yu, "Effects of preheating of crude palm oil (CPO) on injection system, performance and emission of a diesel engine," Renewable Energy, vol. 27, no. 3, pp. 339-351, Nov. 2002.

[105] Pramanik K, "Properties and use of jatropha curcas oil and diesel fuel blends in compression ignition engine," Renewable Energy, vol. 28, no. 2, pp. 239-248, Feb. 2003.

[106] M. Kalam, M. Husnawan, and H. . Masjuki, "Exhaust emission and combustion evaluation of coconut oil-powered indirect injection diesel engine," Renewable Energy, vol. 28, no. 15, pp. 2405-2415, Dec. 2003.

[107] A. J. Mathias and L. Lacrosse, "Emission associated with biomass cogeneration," Wood energy, climate and health - international expert consultation, 1999.

[108] European Pure Plant Oil Association, "Pure Plant Oil (PPO) and Biodiesel (RME) - What is the difference ?" 15-Mar-2011.

[109] A. Demirbas A., "Progress and recent trends in biodiesel fuels," Energy Conversion and Management, vol. 50, no. 1, pp. 14-34, 2009.

[110] S. R. Fore, W. Lazarus, P. Porter, and N. Jordan, "Economics of small-scale on-farm use of canola and soybean for biodiesel and straight vegetable oil biofuels," Biomass and Bioenergy, vol. 35, no. 1, pp. 193-202, Jan. 2011.

[111] B. Esteban, G. Baquero, R. Puig, J.-R. Riba, and A. Rius, "Is it environmentally advantageous to use vegetable oil directly as biofuel instead of converting it to biodiesel?," Biomass and Bioenergy, vol. 35, no. 3, pp. 1317-1328, Mar. 2011.

[112] biodieseltechnologies, "Swot Analysis." 15-Mar-2011.

[113] Ecodyfi., "The Potential for Bio-diesel Fuels in Powys." 2006.

[114] C. Demirbas A., "The global climate challenge: recent trends in $\mathrm{CO} 2$ emissions from fuel combustion," Energy Educ Sci Technol, vol. 22, pp. 179-93, 2009.

[115] K. Dincer K., "Lower emissions from biodiesel combustion," Energy Sources, vol. 30, no. 10, pp. 963-968, 2008.

[116] X. Ou, X. Zhang, S. Chang, and Q. Guo, "Energy consumption and GHG emissions of six biofuel pathways by LCA in (the) People's Republic of China," Applied Energy, vol. 86, Supplement 1, no. 0, p. S197-S208, Nov. 2009.

[117] P. Janulis P., "Reduction of energy consumption in biodiesel fuel life cycle," Renewable Energy, vol. 29, no. 6, pp. 861-71, 2004.

[118] J. Krahl, G. Knothe, A. Munack, Y. Ruschel, O. Schröder, E. Hallier, G. Westphal, and J. Bünger, "Comparison of exhaust emissions and their mutagenicity from the combustion of biodiesel, vegetable oil, gas-to-liquid and petrodiesel fuels," Fuel, vol. 88, no. 6, pp. 1064-1069, Jun. 2009.

[119] W. M. J. Achten, J. Almeida, V. Fobelets, E. Bolle, E. Mathijs, V. P. Singh, D. N. Tewari, L. V. Verchot, and B. Muys, "Life cycle assessment of Jatropha biodiesel as transportation fuel in rural India," Applied Energy, vol. 87, no. 12, pp. 3652-3660, Dec. 2010.

[120] R. Ndong, M. Montrejaud-vignoles, O. Saint Girons, B. Gabrielle, R. Pirot, M. Domergue, and C. Sablayrolles, "Life cycle assessment of biofuels from Jatropha curcas in West Africa: a field 
study," GCB Bioenergy, vol. 1, no. 3, pp. 197-210, Jun. 2009.

[121] J. H. Schmidt J.H., "Comparative life cycle assessment of rapeseed oil and palm oil," International Journal of Life Cycle Assessment, vol. 15, no. 2, pp. 183-197, 2010.

[122] S. Q. A. A. C. J. F. S. Requena, A. C. Guimaraes, S. Q. Alpera, E. R. Gangas, and S. Hernandez-Navarro, "Life Cycle Assessment (LCA) of the biofuel production process from sunflower oil, rapeseed oil and soybean oil," Fuel Processing Technology, vol. 92, no. 2, pp. 190199, 2011.

[123] J. Malça and F. Freire, "Life-cycle studies of biodiesel in Europe: A review addressing the variability of results and modeling issues," Renewable and Sustainable Energy Reviews, vol. 15, no. 1, pp. 338-351, 2011.

[124] L. Reijnders, "The life cycle emission of greenhouse gases associated with plant oils used as biofuel," Renewable Energy, vol. 36, no. 2, pp. 879-880, Feb. 2011.

[125] Chiaramonti D. and L. Recchia, "Is life cycle assessment (LCA) a suitable method for quantitative $\mathrm{CO} 2$ saving estimations? the impact of field input on the LCA results for a pure vegetable oil chain," Biomass and Bioenergy, vol. 34, no. 5, pp. 787-797, 2009.

[126] R. Zah, M. Faist, J. Reinhard, and D. Birchmeier, "Standardized and simplified life-cycle assessment (LCA) as a driver for more sustainable biofuels," Journal of Cleaner Production, vol. 17, Supplement 1, no. 0, p. S102-S105, Nov. 2009.

[127] E. M. Shahid and Y. Jamal, "A review of biodiesel as vehicular fuel," Renewable and Sustainable Energy Reviews, vol. 12, no. 9, pp. 2484-2494, Dec. 2008.

[128] Nwafor O.M.I, "The effect of elevated fuel inlet temperature on performance of diesel engine running on neat vegetable oil at constant speed conditions," Renewable Energy, vol. 28, no. 2, pp. 171-181, Feb. 2003.

[129] E. D. Larson E.D., "A review of life-cycle analysis studies on liquid biofuel systems for the transport sector," Energy for Sustainable Development, vol. 10, no. 2, pp. 109-126, 2006.

[130] E. D. Olzdemir, M. Hardtlein, and L. Eltrop, "Land substitution effects of biofuel side products and implications on the land area requirement for EU 2020 biofuel targets," Energy Policy, vol. 37, no. 8, pp. 2986-2996, 2009.

[131] H. Yang, Y. Zhou, and J. Liu, "Land and water requirements of biofuel and implications for food supply and the environment in China," Energy Policy, vol. 37, no. 5, pp. 1876-1885, May 2009. 